San Jose State University

SJSU ScholarWorks

Master's Theses

Master's Theses and Graduate Research

Spring 2019

\title{
Photovoltaic Waste Management and Implementing Extended Producer Responsibility in the Solar Industry in California
}

Lee-Tan Lu

San Jose State University

Follow this and additional works at: https://scholarworks.sjsu.edu/etd_theses

\section{Recommended Citation}

Lu, Lee-Tan, "Photovoltaic Waste Management and Implementing Extended Producer Responsibility in the Solar Industry in California" (2019). Master's Theses. 5006.

DOI: https://doi.org/10.31979/etd.hqkv-9v4q

https://scholarworks.sjsu.edu/etd_theses/5006

This Thesis is brought to you for free and open access by the Master's Theses and Graduate Research at SJSU ScholarWorks. It has been accepted for inclusion in Master's Theses by an authorized administrator of SJSU ScholarWorks. For more information, please contact scholarworks@sjsu.edu. 


\title{
PHOTOVOLTAIC WASTE MANAGEMENT AND IMPLEMENTING EXTENDED PRODUCER RESPONSIBILITY IN THE SOLAR INDUSTRY IN CALIFORNIA
}

\author{
A Thesis \\ Presented to \\ The Faculty of the Department of Environmental Studies \\ San José State University
}

In Partial Fulfillment

of the Requirements for the Degree

Master of Science

by

Lee-Tan Lu

May 2019 
(C) 2019

Lee-Tan Lu

ALL RIGHTS RESERVED 
The Designated Thesis Committee Approves the Thesis Titled

PHOTOVOLTAIC WASTE MANAGEMENT AND IMPLEMENTING EXTENDED PRODUCER RESPONSIBILITY IN THE SOLAR INDUSTRY IN CALIFORNIA

\author{
by \\ Lee-Tan Lu \\ APPROVED FOR THE DEPARTMENT OF ENVIRONMENTAL STUDIES \\ SAN JOSÉ STATE UNVIVERSITY
}

May 2019
Dustin Mulvaney, Ph.D.
Department of Environmental Studies
Bruce Olszewski, MS
Department of Environmental Studies
Richard Kos, MA
Department of Urban and Regional
Planning




\section{ABSTRACT \\ PHOTOVOLTAIC WASTE MANAGEMENT AND IMPLEMENTING EXTENDED PRODUCER RESPONSIBILITY IN THE SOLAR INDUSTRY IN CALIFORNIA \\ By Lee-Tan Lu}

Electronic waste issues impact humans and the environment, primarily because most industrial designs have not considered the impact of products when they reach their endof-life (EOL) stage. This study focuses on photovoltaic (PV) modules that are widely installed in California residential properties. While PV modules do not generate waste while operating, they will become waste at the end of their expected lifespan of 25 to 40 years. Thus, it is important to identify PV waste management strategies before the materials in the modules become a discard problem. In California, despite hazardous materials that are used in the production of PV modules, there has been no legislative or regulatory action related to PV waste. As a result, the management options and destinations for PV waste are not clear. This study projects the PV waste growth in California, investigates PV waste management, and includes stakeholders' perspectives on the application of extended producer responsibility (EPR) for PV modules. It also estimates the optimal locations for collecting PV waste in the San Francisco Bay Area, which would be an integral action to close the open loop that exists between production and discarding of EOL products. The results of this study revealed that the regulation should be adaptable and may be the key factor to affect the whole value chain of the material loop in the environment. The developed model in this study could be used as a reference in the future to develop a PV waste collection system in California. 


\section{ACKNOWLEDGMENTS}

This research project required extensive networking and professional inputs. It would not have been possible without all the support and interest from several professionals, along with my amazingly caring friends and family. My advisor, Dr. Dustin Mulvaney, has always been responsive and open to discussing the research methodologies, exploring possibilities for potential research topics, and sharing related literature with me. Professor Bruce Olszewski has introduced me to a variety of different workshops, conferences, and meetings which connected me to a vast number of stakeholders in the industry, ranging from the private sector to governmental representatives. Lastly, learning from and working with Professor Richard Kos, who is very experienced in using ArcMap and ArcGIS Online, helped me extensively on doing Hot Spot Analysis, using Network Analyst, and creating choropleth maps. Conducting graduate research has been the most challenging and fulfilling task I have ever done; I express infinite appreciation to those who have been supporting me throughout the learning and research process. 


\section{TABLE OF CONTENTS}

List of Tables .................................................................................................... viii

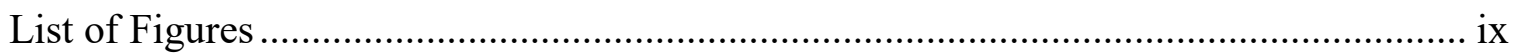

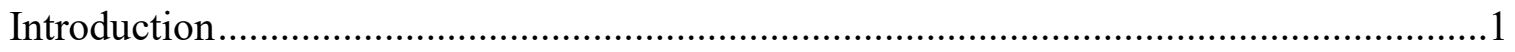

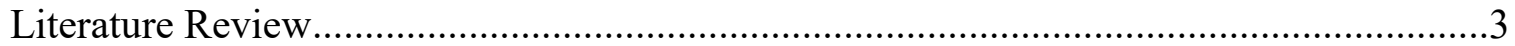

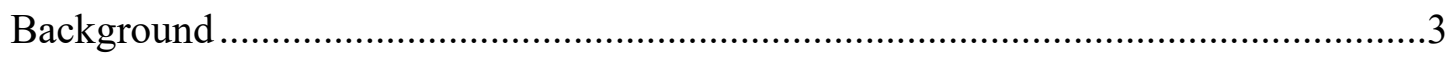

Linear Economy versus Circular Economy .....................................................

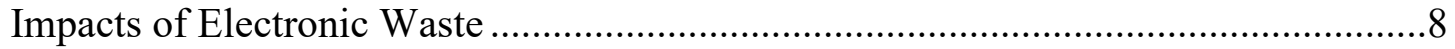

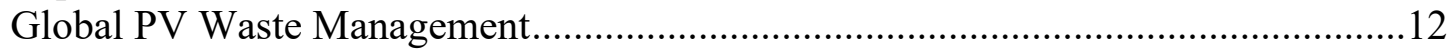

PV Waste Management in the United States ...................................................... 14

Problem Statement and Research Questions..........................................................16

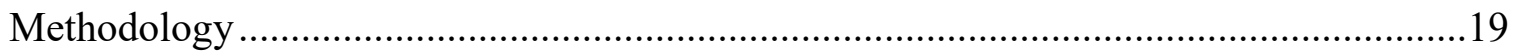

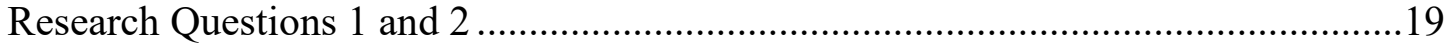

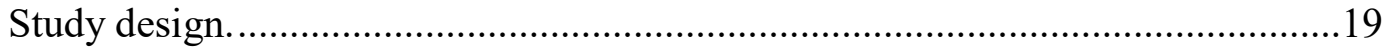

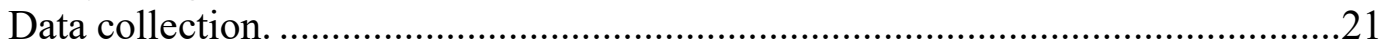

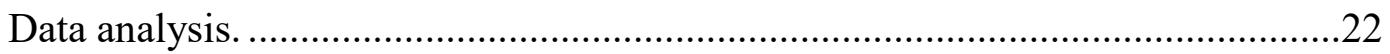

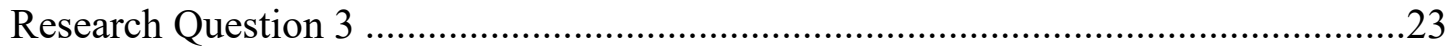

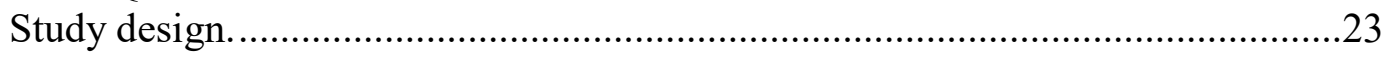

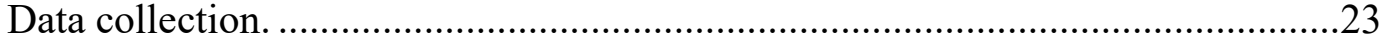

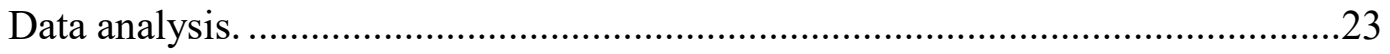

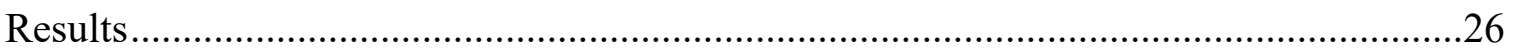

Research Question 1: What are the photovoltaic waste flows anticipated in the San Francisco Bay Area, California? ...................................................................26

Research Question 2: What are stakeholders' perspectives on extended producer responsibility for photovoltaic waste? ................................................................28

Research Question 3: Where are the optimal locations for collecting photovoltaic waste in the San Francisco Bay Area? .................................................................. 30

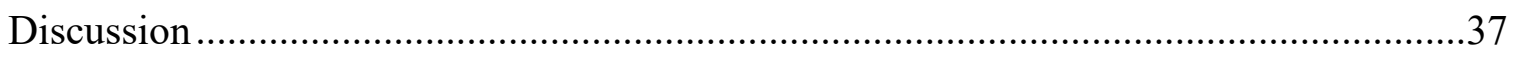

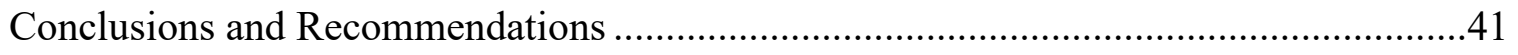

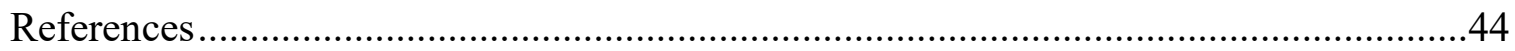

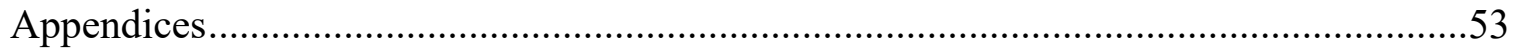

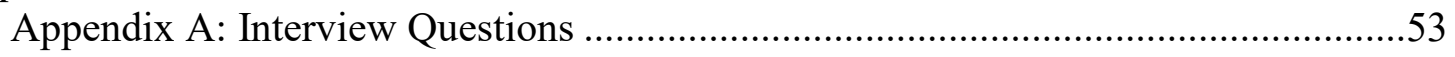

Appendix B: PV Waste Flow and Interview Questions.........................................55

Appendix C: EPR and stakeholders and interview questions ..................................56 
Appendix D: Consent Form for Participation in Research ......................................57

Appendix E: Methodology for PV Waste Projection ..............................................60

Appendix F: Methodology for Map Creation and GHG Calculation .........................64 


\section{LIST OF TABLES}

Table 1. Number of Potential/Actual Participating Interviewees .............................. 26

Table 2. List of Participating Interviewees by Stakeholder Type .............................. 27

Table 3. Average Distance from PV Waste Sources to the Optimal Collection Centers and Generated Greenhouse Gas (GHG) Emissions ......................... 34 


\section{LIST OF FIGURES}

Figure $1 . \quad$ The solar industry supply chain ....................................................... 1

Figure 2. Resource flows within a circular economy .......................................... 6

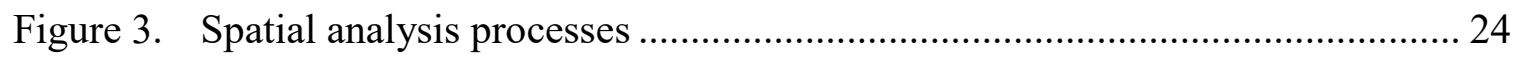

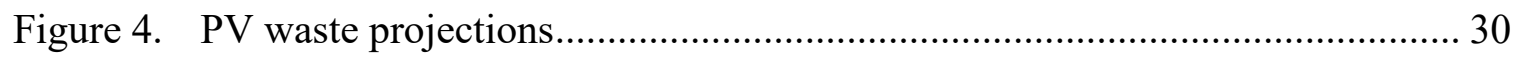

Figure 5. PV waste distribution in the San Francisco Bay Area ................................ 31

Figure 6. Hot spots analysis of projected PV waste volume ..................................... 33

Figure 7. Simulated PV waste flow from San Francisco Bay Area to Apex Landfill.... 35

Figure 8. Simulated PV waste collection network with three collection centers ........... 36 


\section{Introduction}

With the growing public awareness of climate change, sustainability has become an important practice for securing the prosperity of human beings and the environment. One concern is the increasing demand for limited availability of energy due to finite conventional energy sources, as well as the surging demand for primary metals (McLamb, 2011; U.S. Geological Survey, 2018). Electricity from photovoltaic (PV) modules is one of the renewable energy options that can reduce household, commercial, and industrial electricity costs while decreasing environmental impacts compared with traditional energy generators (Holowka, 2017). However, the expected lifespan for PV modules averages 30 years (IRENA and IEA-PVPS, 2016), which will create a PV discard management challenge, and perhaps a material management crisis.

To date, few PV waste manufacturers operate recycling programs, and there are few mandated PV waste regulations globally. California has been a world leader in transitioning to PV technology adoption, and the state will have to face the looming issues resulting from PV waste. To close the loop of the current linear manufacture-usediscard pattern in the PV industry, this study investigates the treatment of PV waste in California by interviewing stakeholders in the PV value chain (Figure 1).
Manufacturer
Installer
Customer
E-Waste
Recycler

\section{NGO and Local Government/Jurisdiction}

Figure 1. The solar industry supply chain. 
This research also illustrates fundamental insights on current PV waste management practices with maps and re-constructed waste flows. This information can be used as a tool to ameliorate environmental and cost challenges inherent in the current linear system for the benefit of improved material management for the future. 


\section{Literature Review}

\section{Background}

PV modules are one of the renewable energy resource options used throughout the world to overcome the pressure of limited resources and reduce air pollutants. To generate electricity for the growing demands of the $21^{\text {st }}$ century, the installation of PV modules is expected to increase rapidly in the coming years. However, the lifespan of PV modules is estimated at around 25 to 40 years. They will become a significant source of electronic waste (e-waste) within this decade. In fact, there will be about 78 million metric tons of e-waste contributed by PV modules by the year 2050 (IRENA and IEAPVPS, 2016). Increased waste is the consequence of product design, which fails to consider the environmental impacts when the products reach their end-of-life (EOL) phase (Guide Jr., Harrison, \& Wassenhove, 2003; Ohno, 2014; Tansel, 2017).

A variety of compounds are used in PV modules; some compounds - including silver, aluminum, indium, gallium, and tellurium - have a high value for recycling and recovery (Moss, Tzimas, Kara, Willis, \& Kooroshy, 2014). However, compounds such as aluminum, cadmium, and selenium are considered to be hazardous chemicals that will harm the environment when disposed of improperly (EPA Resource Conservation and Recovery Act (RCRA) Regulations, n.d.). A further consideration is that the availability concerns about precious materials such as silver, indium, and tellurium can limit the PV industry growth; these are scarce resources and recycling of these materials is not widespread (Fthenakis, 2009; Marwede, Berger, Schlummer, Maurer, \& Reller, 2013; Zuser \& Rechberger, 2011). Being material source independent becomes even more 
important for the defense industry because foreign suppliers are becoming unstable (U.S. Department of Defense, 2018). One example is aluminum, which is largely used for aircraft and gallium arsenide for night-vision systems (U.S. Department of Defense, 2018). In order to achieve long-term success in the PV industry, material recovery and conservation — such as waste management that encourages recycling and product design that incorporates recycled content—is critical.

\section{Linear Economy versus Circular Economy}

The existing economic model commonly found among industries is based on a linear economy, in which raw materials are extracted from the environment, processed, manufactured into products, transported, used, and then discarded as waste when the products reach their end of life (Ellen MacArthur Foundation, 2012). Georgescu-Roegen (1971) stated that extracted raw materials are irreversible when put to use for economic activities and that they also increase entropy in our environment. Developing countries such as China are experiencing rapid development; in China, for example, average income is growing ten times faster when compared to the United Kingdom's economy during the Industrial Revolution, with 100 times as many citizens (Dobbs, et al., 2013). This rapid developmental growth in Asian countries has resulted in increased demand for raw materials, both from domestic sources and abroad, to build housing for an everincreasing population, and to keep pace with transportation infrastructure, household commodity items, and more, while at the same time causing volatility in the pricing of raw materials (Dobbs, et al., 2013). 
In order to become resource independent and to minimize pollution, changing the linear economic pattern is essential to overcoming the accompanying environmental degradation caused by primary materials extraction and processing (van Buren, Demmers, van der Heijden, \& Witlox, 2016). The circular economy is the opposite of a linear economy; by directing discards or "waste" back into the material flow, a continuous closed-loop cycle is maintained (Figure 2). This circular pattern reduces waste by improving efficient use of extracted raw resources. The Ellen MacArthur Foundation (2012), defines five principles of the circular economy, which are summarized as:

1. No waste within the system - all components are designed to fit in the biological or technical materials cycle. Biological elements are nontoxic and compostable, and technical elements are designed to be reused or refurbished for best quality output with minimal energy consumption;

2. Diversity brings resilience - the multiple connections and scales within the system are stronger than a uniform system for efficiency;

3. Adopt renewable sources for energy - it is appropriate to apply pressure on increasing efficiency to ensure no labor or energy shortage;

4. Systems thinking - the connection and flow of each part, and how it will influence other parts of the system, is taken into account;

5. Waste is the nutrition of the system - biological waste returns back to the biosphere and technical waste can be upcycled back into manufacturing processes. 
Since the early 2000s, the European Union and the Chinese government have proposed laws, based on circular economy principles, which address waste and resources, eco-design, and green consumption (Saavedra, Iritani, Pavan, \& Ometto, 2018). The circular economy can be used as a regenerative system to minimize resource input and waste leakage by slowing and closing the material loop (Geissdoerfer, Savaget, Bocken, $\&$ Hultink, 2017). In general, a circular economy helps to maximize the function of all resources, and includes the improvement of product efficiency, shifting to renewable energy and materials, and promoting product lifespan through maintenance and design, et cetera. McKinsey \& Company (2017) demonstrated that a circular economy could boost Europe's resource productivity three percent by 2030, generating cost savings of almost $\$ 700$ billion a year (Figure 2).

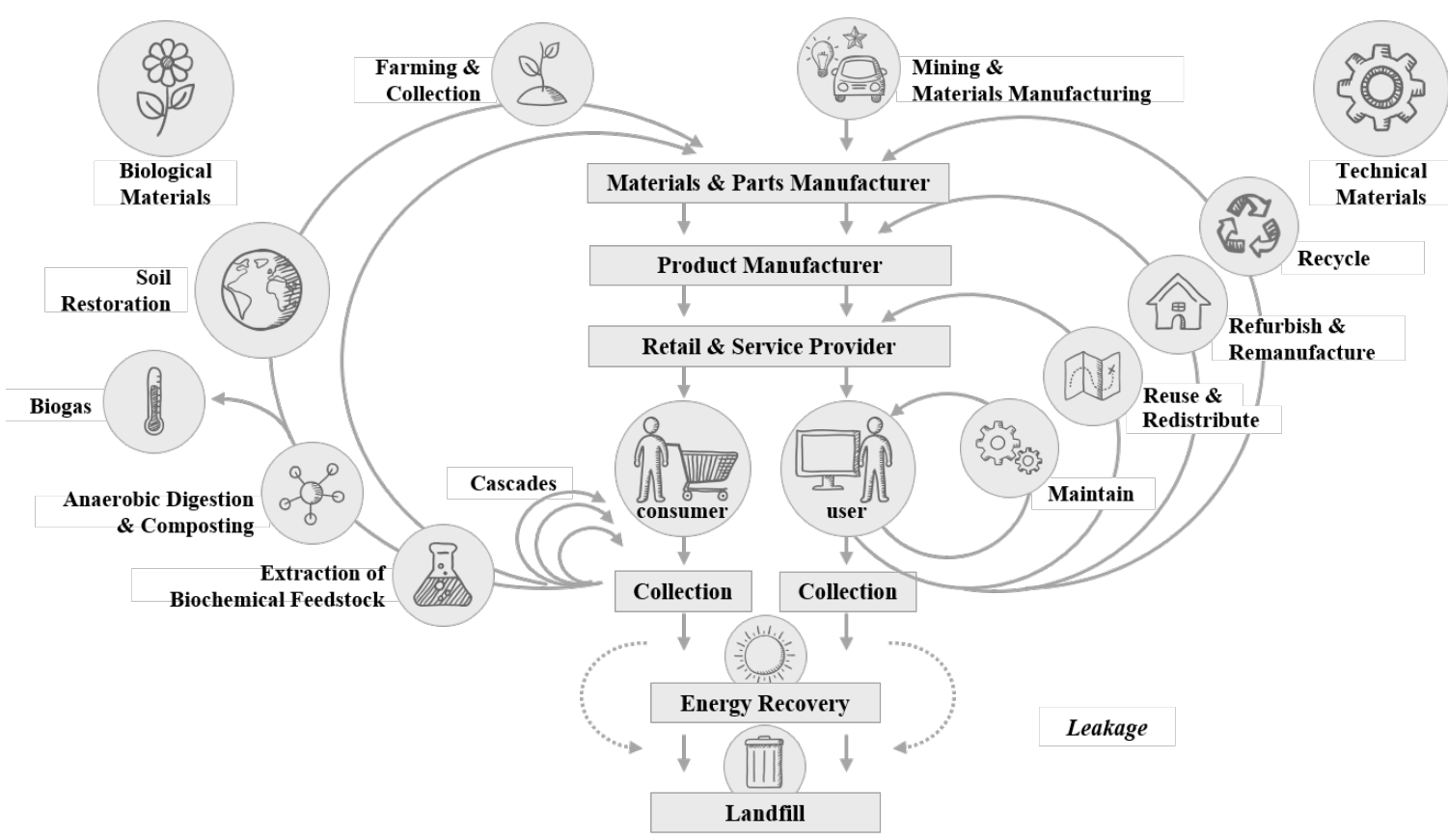

Figure 2. Resource flows within a circular economy. There are two dominant flows: biological and technical. Resources regenerate and process without human intervention in the biological cycle; in the technical cycle, humans recover and recreate materials with sufficient energy. Adapted from Ellen MacArthur Foundation, 2014. 
The long-term benefits of a circular economy have been proven by companies such as Renault, a car manufacturer committed to closing the loop at vehicle EOL. For every newly manufactured Renault vehicle, thirty-six percent of its mass is produced with recycled materials, and at EOL, $85 \%$ of the vehicle is recyclable (Ellen MacArthur Foundation, n.d.). As a circular economy pioneer among car manufacturers, Renault has grown their remanufacturing operation into a 200-million-euro business (Ellen MacArthur Foundation, 2012).

Despite the apparent long-term benefits of a circular economy, the process of changing economic patterns is complicated. Companies would need to develop methods for managers to show the benefits gained from new business models (Geissdoerfer et al., 2017). To incentivize desired outcomes, long-term strategies are often required to compensate the initial investment needed to develop evolved business models (Ellen MacArthur Foundation and McKinsey \& Company, 2014). Lastly, companies would need to adapt to new operational models to manage daily business objectives (Guide Jr., Harrison, \& Wassenhove, 2003). In addition to policies that can drive change in the overarching economic model, companies should also identify the importance of logistics and the development of the products themselves in order to truly have holistic business improvement (Buren et al., 2016; Choi \& Fthenakis, 2010a).

In the case of PV modules, Choi and Fthenakis (2014) found that material collection costs, which includes fuel price, labor, and logistics, have a larger effect on profits than do recycling technologies, processing costs, and capital costs. Thus, collection points and networks among stakeholders are critical for the industry to maintain cost-effective 
operations. In order to transition the business model to a circular economy approach, integrative decisions are needed on a company and inter-company level, with a systemic perspective on waste, natural resources, and economic issues (Lieder \& Rashid, 2016).

\section{Impacts of Electronic Waste}

Electronic waste (e-waste) has become a problem in our society and environment; improper e-waste management and an absence of strict government regulation have and will continue to cause human health impacts. More than $60 \%$ of e-waste consists of metals, of which about $2.7 \%$ are toxic metals such as mercury, cadmium, and lead (Hossain, Al-Hamadani, \& Rahman, 2015). In spite of this level of toxicity, only $10 \%$ to $15 \%$ of global e-waste is separated from landfills (Saranga, 2014, as cited in Hossain, 2015). The most common e-waste recycling practice in the world is transporting e-waste to developing countries such as China, Sri Lanka, and Bangladesh (Hossain et al., 2015; Tansel, 2017).

In 2016, 44.7 million tons of e-waste was generated globally: $40.7 \%$ was generated in Asia, followed by Europe with 27.5\%, and the Americas with 25.3\% (Balde, Forti, Gray, Kuehr, \& Stegmann, 2017). Developed countries are categorized as the main source countries for e-waste that is then transported to destination countries such as China, India, and Africa (Balde, Wang, Kuehr, \& Huisman, 2015). E-waste is transported to other developing countries primarily because of the low-cost of processing when compared to costs in developed countries. For example, it costs 20 dollars to recycle a computer in the United States, but less than 2 dollars in Bangladesh, India, and Pakistan (Hossain et al., 2015). However, according to Nixon, Saphores, Ogunseitan, and Shapiro (2007), the low 
cost of recycling should not be the reason to transport e-waste into developing countries, especially when they lack awareness of on-site environmental health and safety practices.

Pervasive pollution incidents and related issues have raised concern on a global scale that the e-waste problem should be monitored and reduced. According to a report from the Environment and Social Development Organization (ESDO), the lack of an efficient e-waste management system has caused the illness or death of children: approximately $83 \%$ were exposed to long-term health impacts and an estimated $15 \%$ have died as a result of illegal child labor practices in Bangladesh (Hossain, Sulatan, Shahnaz, Akram, Nesa, \& Happell, 2010). Informal recycling activities in Pakistan have caused contamination of the marine ecosystem and have impacted marine life due to the dumping of e-waste into the Lyari River (Khan, Lodhi, Akhtar, \& Khokar, 2014). Informal e-waste recyclers also dominate the e-waste collection in China as a result of convenient home collection and additional payment for outdated appliances (Salhofer, Steuer, Ramusch, \& Beigl, 2016). Yang, Lu, and Xu (2008) suggest that informal recyclers should be certified in order to build a safe and effective collection network.

One of the strategies to cope with the e-waste issue is extended producer responsibility (EPR), an environmental policy popularized by the Organisation for Economic Cooperation and Development (OECD) which extends producers' responsibilities for the products to the post-consumer stage of the products' life cycle (Organisation for Economic Co-operation and Development, 2001). There are two related features in EPR: (1) shifting responsibility toward the producers for the duration of the product lifecycle, and (2) providing incentives to producers to incorporate environmental 
considerations upfront in the product design stage (Organisation for Economic Cooperation and Development, 2001). Several countries have adopted EPR for particular ewaste categories: the Netherlands has a focus on information technology (IT) equipment, Switzerland's focus is on electronic appliances, and Japan's focus is on large household appliances (Organisation for Economic Co-operation and Development, 2001). Unlike these countries, the United States federal government has not acted to give itself the authority to require that EPR take-back programs be implemented on a national scale. The United States Environmental Protection Agency (EPA) enforces requirements for hazardous waste management under the Resource Conservation and Recovery Act (RCRA), which includes handling, treatment, storage, and disposal, but the regulations do not cover the imminent PV waste (United State Environmental Protection Agency, n.d.).

In spite of no federal action with respect to EPR policy implementation, some American states have moved forward on the issue. The state of Maine voluntarily adopted EPR for television and computer monitors in 2004 (Kiddee, Naidu, \& Wong, 2013). California adopted EPR legislation for industries to collect and process discarded carpet, mattresses, paint, cell phones, and some additional types of e-waste, due to the predicted large waste volume and rare metals contained in the products (CalRecycle, 2015a). EPR regulations for other products, such as gas cylinders, are being processed by regulators (California Product Stewardship Council, n.d.). Currently, there is only one gas cylinder manufacturer that has engaged in a redesign of their products to enable refilling; the majority of used gas cylinders must be disposed of (California Product Stewardship Council, n.d.). Batteries are another targeted product in need of an EPR program. The 
risks of disposing batteries in the trash include environmental contamination and fire incidents in waste processing plants (California Product Stewardship Council, n.d.).

In the U.S., the methods and infrastructure for collecting and processing e-waste are not yet well established. The major challenges are creating public environmental awareness, having a continuous and stable waste supply, and developing cost-effective technologies for recycling (Kang \& Schoenung, 2005). The most two most common ways to treat e-waste are landfill disposal and exportation to other countries. Without the federal government's direction, states established their own e-waste policies (Kahhat, et al., 2008). The primary department in charge of e-waste in California is the Department of Toxic Substance Control (DTSC), a sub-agency of the California Environmental Protection Agency (CalEPA). The state adopted California Code of Regulations Chapter 23 , which dictates that while certain hazardous wastes, such as batteries and mercurycontaining equipment, are universal waste to be kept away from landfills, they can still be handled and transported under more relaxed rules when compared to true hazardous waste (California Department of Toxic Substances Control, n.d. ${ }^{a}$ ). E-waste contains hazardous materials that must be processed by designated recyclers for proper treatment (California Department of Toxic Substances Control, n.d.). Senate Bill 489 would authorize DTSC to designate PV waste as universal waste and to develop a comprehensive system for reuse, recycling, and safe disposal of the PV waste (California Legislative Information, 2015; California Product Stewardship Council, n.d.). 


\section{Global PV Waste Management}

Renewable energy has become popular as an alternative electricity source in the world. Traditional PV markets in Europe and North America have grown over 5\%, and PV capacity in Asia increased 50\% in 2015. However, PV modules are constrained by their limited lifespan (IRENA and IEA-PVPS, 2016). Though the PV industry is comparatively new and PV modules have a long projected lifetime, waste treatment strategies and regulations still need to be considered, since PV modules contain valuable elements like silver, silicon wafer, and indium, as well as heavy metals such as copper, cadmium, and lead (Eberspacher \& Fthenakis, 1997). Several studies claimed that policies with economic motivation are needed to encourage the PV industry (and other energy industries) to develop sustainable strategies (Besiou \& Wassenhove, 2015; Tao \& Yu, 2015; Zeng, Duan, Wang, \& Li, 2017). A workshop report from 1992 pointed out that the PV industry should consider both Environmentally Conscious Manufacturing (ECM) and Design for the Environment (DfE) concepts to minimize environmental impact (Moskowitz \& Zweibel, 1992). In the report, they indicated that PV industry should designed for easily disassembling by recyclers and the containing materials should be recycled, reduce generated waste throughout the process, and reduce quantity of rejected modules through quality control et cetera (Moskowitz \& Zweibel, 1992).

Germany became an early solar energy adopter in the 1990 s and is on track to become the first and largest market for PV recycling. The country's PV systems contributed $6 \%$ of total net electricity consumption in 2015 (IRENA and IEA-PVPS, 2016). In 2015, the German government established the Electrical and Electronic 
Equipment Act via the National Register for Waste Electrical Equipment, which requires the collection and recycling of all decommissioned e-waste and PV modules (Stiftung EAR, n.d.). As a member of the European Union, Germany is in line with the latest Waste Electrical and Electronic Equipment (WEEE) Directive, also updated in 2015, which states that any PV module producer must provide collection, recovery and recycling treatments for each new module sold (Solar Waste, n.d.).

While Japan has also been a PV industry pioneer contributing research and development in the PV industry, the Japanese PV market is small compared with other countries (IRENA and IEA-PVPS, 2016). It has no specific regulation for PV waste, which means that at present the decommissioned modules will be treated under general waste management rules (METI and Ministry of Environment, 2015, as cited in IRENA, 2016). Still, in spite of its small market size, Japan is leading the way. The Japanese Ministry of Economy, Trade, and Industry (METI) and the Ministry of the Environment (MOE) have been working jointly to address the decommissioned energy equipment regulations since 2013 (METI and Ministry of Environment, 2015, as cited in IRENA, 2016; Ministry of Economy, Trading and Industry, 2015). Although Japan has a smaller PV market, they are already conducting PV waste recycling projects under the New Energy and Industrial Technology Development Organization (NEDO) regulation. Longterm tests are expected in order to verify the performance at industrial scale (Noda et al., 2014). 


\section{PV Waste Management in the United States}

In the U.S., Washington State requires solar manufacturers to finance or manage a product stewardship program for their sold units within the state after July 1st, 2017 (Reykdal, 2017); New York State also reintroduced the "Solar Panel Collection Act" in 2018 by working with manufacturers to collect and recycle the out of service solar modules in order to prevent PV waste from being disposed into landfills (O'Mara, T. F., 2018; The Evening Tribune staff, 2018). In general, PV waste is under-monitored by RCRA, as there are no specific regulations for PV waste on a national scale. California's solar energy generating capacity is greater than any other state (U.S. Energy Information Administration, 2016), but the state has no documented research regarding PV waste management or stakeholders' perspectives for EPR within the state. The DTSC is expected to list PV waste as universal waste, which will separate PV waste from the general hazardous waste and landfill classifications. This lack of an effective PV waste management strategy suggests that more efforts are needed to investigate PV waste management in California and understand stakeholder perspectives with respect to EPR to protect human and environmental health and conserve resources.

The exploratory nature of a case-based research design is a practical method to obtain direct information from the PV industry (Besiou \& Wassenhove, 2015). Besiou and Wassenhove (2015) conducted their study by interviewing several global PV industry stakeholders - manufacturers, installers, e-waste recyclers, and PV-related organizations. Research conducted by Hendrickson et al. (2015) used Geographic Information Systems (GIS) to optimize the dismantling facilities' location between collection points and final 
recycling destinations in California. This reverse logistic model type of network is designed for allocating the optimized location between sources of the waste and the collection centers (Choi \& Fthenakis, 2014). Similarly, Acar et al. (2015) also applied GIS to determine the locations of return centers to improve reverse logistic network in Turkey. 


\section{Problem Statement and Research Questions}

Waste management decisions have been increasingly discussed in recent years because of increasing quantities of waste and their impacts on local societies and the environment, particularly by the electronics industry (Hoornweg, Bhada-Tata, \& Kennedy, 2013). The majority of electronic products contain different metals, $2.7 \%$ of which are toxic, such as aluminum, cadmium, chromium, and mercury (Hossain et al., 2015). The problem of e-waste toxicity — which threatens human health with both acute and chronic conditions - has been documented in developing countries which are experiencing rampant e-waste dumping (Tansel, 2017). Researchers have found toxic substances concentrated in blood, hair, and urine of illegal child laborers in China and the other developing countries (Hossain et al., 2015; Kiddee, Naidu, \& Wong, 2013).

With increasing e-waste and climate change issues, some industries are beginning to develop products and services—-such as replacing conventional energy facilities with renewable solar, wind, and tidal energy facilities - that might be able to ameliorate the pollution and resource scarcity problems. PV modules are an example of renewable energy technology because they absorb sunlight and convert it into electricity, and they also largely reduce greenhouse gas emissions (Breyer, Koskinen, \& Blechinger, 2015; U.S. Energy Information Administration, 2017). In fact, the global installation of PV modules grew significantly in 2015, with a $12.4 \%$ increase in new markets in Asia and an increase of $6.3 \%$ in PV module installations in a mature market like North America. Still, there are only few countries in the world that have strategies to deal with an imminent PV waste management problem (IRENA \& IEA-PVPS, 2016). As the first country to invest 
in PV modules in the 1990s, Germany expected 3,500 to 70,000 tons of PV waste by 2016. In preparation for an influx in PV waste, Germany revised the European Union WEEE Directive to require that PV manufacturers implement EPR for their PV modules (IRENA \& IEA-PVPS, 2016). Despite EPR programs in Europe, there is no similar federal law in the United States or any information about how stakeholders might perceive EPR strategies for EOL management of PV modules.

California has converted to $29 \%$ of its energy coming from renewable source (California ISO, 2017). Additionally, California accounts for nearly half of the United States' solar electricity generating capacity and was expected to face over 13,000 tons of PV waste by 2020 (IRENA \& IEA-PVPS, 2016; U.S. Energy Information Administration, 2016). However, there is no well-documented research regarding PV waste flows in California. Furthermore, PV systems are increasingly co-sited with lithium-ion batteries to store the collected energy; improper recycling programs for PV systems, both with and without lithium-ion batteries, will waste natural resources and result in environmental hazards (Gibson \& Kelly, 2010; Li, et al., 2014; Zipp, 2015). Gu et al. (2017) also pointed out that battery leakage of organic substances and heavy metals will cause serious soil contamination if the waste is directly dumped into a landfill.

In addition, due to the lack of e-waste processing infrastructure in the United States, China became the top recipient of Californian recyclable materials. China started to ban the imported waste, thereby increasing pressure on both producers to design and jurisdictions to manage the emerging new wave of PV waste (CalRecycle, 2018b; Kang \& Schoenung, 2006). Among all recycling activities, reverse logistics were identified as 
the major cost compared with operational costs, recycling processing costs, and labor costs (Choi \& Fthenakis, 2014, 2010b). California's current PV waste levels represent a small fraction of all types of e-waste; still, having decentralized processing capacity can prevent PV waste from going into landfills and can translate to economic and environmental benefits (Choi \& Fthenakis, 2010a). When transitioning from short-term recycling programs to longer-term programs which do not rely on exporting waste to other states or countries, the first stakeholders to benefit become the reverse logistics companies and primary metal smelters (Eberspacher \& Fthenakis, 1997).

The purpose of this study was to investigate PV waste flows in California and understand stakeholders' views on EOL management. Interviews were conducted with a variety of PV stakeholders including manufacturers, installers and e-waste recyclers to understand their perspectives of EPR as a potential strategy for mitigating PV waste. After the interview phase, the study then focused on the San Francisco Bay Area region, and applied GIS to evaluate optimal locations for collection facilities to most effectively capture PV waste and prevent pollution. This thesis asked the following research questions:

1. What are the photovoltaic waste flows anticipated in the San Francisco Bay Area in California?

2. What are the stakeholders' perspectives on extended producer responsibility for photovoltaic waste?

3. Where are the optimal locations for collecting photovoltaic waste in the San Francisco Bay Area? 


\section{Methodology}

\section{Research Questions 1 and 2}

Study design. California is currently on track to process large quantities of PV waste over the next decade, yet the corresponding PV waste management system is not transparent. Many solar projects will potentially fall out of the scope of current regulations. Thus, it is crucial to consider how similar systems are handled in other regions throughout the world, including European countries (IRENA and IEA-PVPS, 2016). This study explores the PV waste management issue and considers the experience of other comparable regions in Europe and the United States. All interview questions were designed to be open-ended and semi-structured, which allowed respondents to answer without restrictions based on their experience in the industry. Interviews were conducted, either in person or by phone, depending on both the researcher's and respondents' availability. However, due to the sensitivity of the topic within the industry, some of the interviewees requested to withhold their name and/or work title. Interview questions are specified for each stakeholder's operation in Appendix A.

With regard to PV waste flows, manufacturers, installers, and e-waste recyclers are assumed to be interrelated (Besiou \& Wassenhove, 2015; Lieder \& Rashid, 2016; Yang, $\mathrm{Lu}, \& \mathrm{Xu}, 2008)$. Appendix B shows the relationship between these participants and their specific responses concerning Research Questions 1 and 2, related to PV waste management within California. EPR is defined such that the manufacturer of the product should be responsible for the product across its entire life cycle (Organisation for Economic Co-operation and Development, n.d.). This policy strategy appears to be 
implemented in many European countries, such as Switzerland, Germany, and the Netherlands (Li, et al., 2013). EPR is applied to batteries, EOL vehicles, monitors, refrigerators, and more (European Commission - DG Environment, 2014). In Switzerland, for example, stakeholders have fulfilled their EPR responsibility and as a result have reduced e-waste landfill residuals to only 2\% (Khetriwal, Kraeuchi, \& Widmer, 2009). California, which only has EPR programs for carpet, mattresses, and paint (CalRecycle, 2018a), can benefit from the experience of EPR used in other regions of the world. Appendix C depicts stakeholders' stances in relation to EPR and the corresponding EPR-related interview questions.

During the interviews, the questions about PV waste flows were primarily directed to manufacturers, since they design and/or manufacture PV modules which may result in waste at EOL. The questions were either correlated with prolonging PV products' lifespan or with the process of PV waste treatment. E-waste recyclers and NGOs are also considered in this section because they may have better knowledge of a current, though comparatively small, amount of PV waste in the e-waste stream.

For the EPR section of the interview questions, manufacturers would be directly impacted once policy is mandated by the government. The questions are associated with whether the company should implement EPR voluntarily to avoid legislation, regulation, and enforcement. Since few PV organizations have recycling projects for PV waste in European countries and the United States, the EPR questions focused on potential collaborations between stakeholders during the collection process. Installers are also part of the network under EPR because successfully removing PV modules requires 
professional techniques, which in turn help streamline reverse logistics procedures. Due to the current low quantity of PV waste and related legislation, there are no e-waste recycling centers that accept PV waste in California. One of the certified companies, Santa Clara based e-waste recycler, ECS Refining, was able to process PV waste, but filed bankruptcy to avoid takeover from their investment partner in 2018 (Elliott, 2018; Paben, 2018). However, because PV waste is predicted to increase within a few years, other informal e-waste recycling centers will become more critical in helping to manage PV waste in the short term (Yang, Lu, \& Xu, 2008). Hence, e-waste recyclers are also recognized as stakeholders in this study. Taking these factors account, EPR interview questions focus on the acceptance and treatment of PV waste.

Data collection. Due to limited time and travel budget, this study includes interviews with fifteen respondents. Each respondent indicated their role in the corresponding PV supply chain. All respondents were in sustainability or other related departments in their company or organization. Because the awareness of PV waste was not widespread in California, this study adopted snowball sampling as a strategy to acquire the information for Research Questions 1 and 2. The researcher identified potential respondents from both professions related to the researcher's academic advisors, and by attending workshops and conferences related to PV. The conferences and workshops included the following six events: Northern California Recycling Association's Recycling Updates conference, Verge17, California Higher Education Sustainability Conference, California Resources Recovery Association's Annual Conference \& Tradeshow, the City of San Jose's Leading Climate Innovation-The Silicon Valley Way, and Berkeley's Resources 
Roundtable: Innovation in Waste Management. Once the potential interviewees expressed their willingness to participate in the research interview, the researcher scheduled the meeting time and arranged the required equipment, such as a laptop and recorder for recording the audio content. All interviews were conducted either in person, online (by Skype or Zoom), or by phone. The researcher first sent the research consent letter for the interviewees - approved by SJSU Humans Subjects Research Institutional Review Board (IRB); the interview would start after receiving the signed consent letter. The IRB-approved consent letter can be found in Appendix D.

Data analysis. The interviews were transcribed into Microsoft Word documents. The data were organized and labeled by reading the content and identifying each response framework using the ATLAS.ti 8 software (Lewis, 2004). Next, the data were coded by using narrative analysis to reformulate respondents' answers based on their different contexts and experiences. For instance, if a respondent implied that the company would recycle PV waste in the future, the researcher labeled the keywords from transcripts to support the respondent's answer. The logic of the respondents' answers was presented by the software layout and helped the researcher to objectively confirm and categorize the respondents' opinions. Secondary information, such as reports from official websites, was also used to inform the study and improve its thoroughness. The relevant interview summaries were sent to each respondent for approval before the conclusion of the study.

For the informal interview data, based on the willingness of the interviewees and restrictions of the IRB, identity-related information is not allowed to be disclosed. All the answers obtained from informal interviews were taken as a supplement to this research. 


\section{Research Question 3}

Study design. With the increasing number of PV system installations in California, evaluating the ideal locations for collection and recycling centers could help PV waste to be processed with less cost and minimized environmental impact. Additionally, based on the information that was obtained from the interviews for Research Questions 1 and 2, associated parameters regarding operational costs were factored into the estimation and comparison of different potential location scenarios. This study applied ArcMap and ArcGIS Online to address Research Question 3, which calculated the locations of potential recycling centers based on estimated PV waste volume and then distances to reach them, using the San Francisco Bay Area's road system.

Data collection. Raw data were acquired from California Distributed Generation Statistics (2018) in order to determine the locations of PV installations. The data were aggregated and measured by zip code as geographic units in the San Francisco Bay Area. Then, the Weibull function to project PV waste growth (see equation 1.0) and alpha shape factors used by IRENA and IEA-PVPS (2016) were applied in Microsoft Excel 2016 to calculate the PV waste volume growth until the year of 2050. The detailed information regarding the estimation of PV waste growth over time is in Appendix E.

$$
\begin{aligned}
& \text { where } \quad F(t)=1-e^{-\left(\frac{t}{T}\right)^{\alpha}} \\
& t=\text { time in years } \\
& T=\text { average lifetime } \\
& \alpha=\text { shape factor, which controls the } \\
& \text { typical S shape of the Weibull curve }
\end{aligned}
$$

Data analysis. The first step was to visualize PV waste growth in the Bay Area.

Graduated symbols were used in ArcMap 10.6.1 to present the PV waste volume within 
zip code areas, with the point positioned in each zip code's centroid. As for assessing optimal locations of collection and recycling centers, ArcGIS Online's (AGOL) “Analyze Patterns - Find Hot Spots" function was used to determine if a given zip code area has significantly higher PV waste than neighboring areas. The identified hot spots with significantly higher PV waste sources were used to estimate their distance to the nearest center. In this case, those hot spots were grouped together as the target to help determine where the collection centers would optimally be sited (Figure 3). AGOL's "Summarize Data - Summarize Center and Dispersion" function was used to identify the location of the potential collection centers, assuming different numbers of PV waste collection site scenarios.
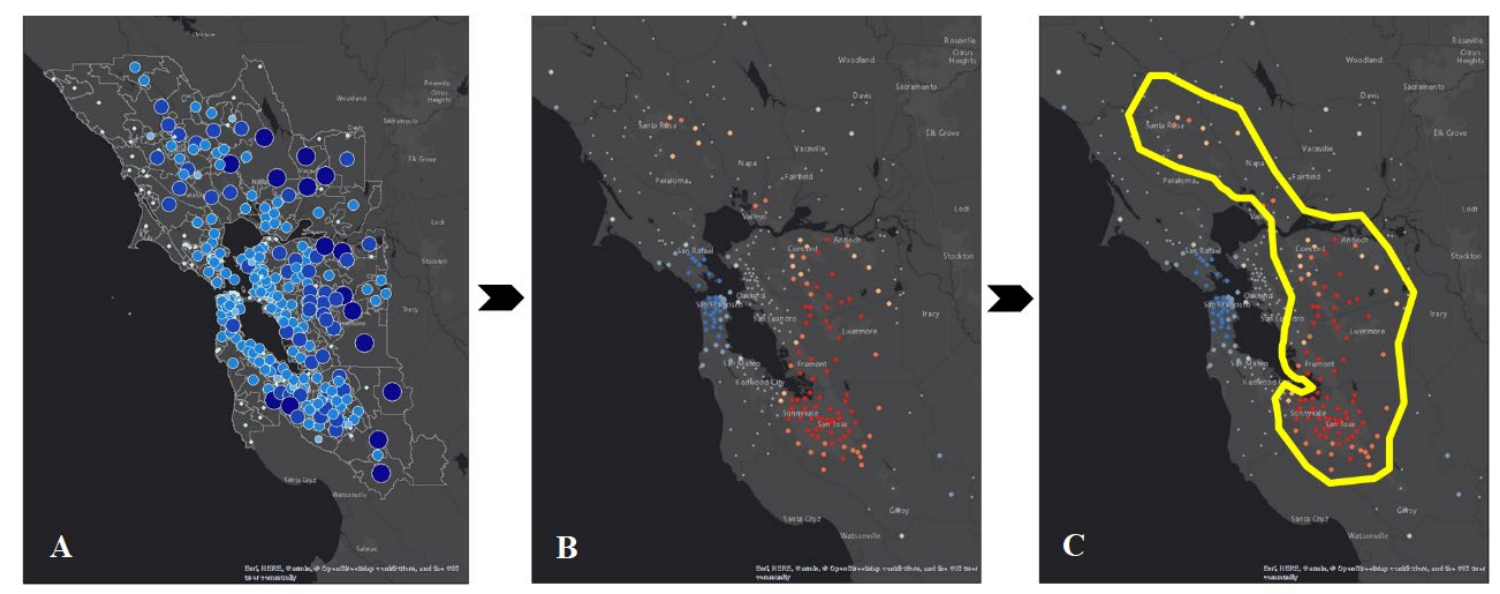

Figure 3. Spatial analysis processes. From the left to right pictures depict the procedures to identify (A) Graduated Symbol map which highlights the PV waste sources in the Bay Area; (B) Hot Spots Analysis map which shows the "hot spots"-places which have significantly higher waste volume - in red; and finally (C) shows a map in which the irregular shape in yellow highlights major hot spots for Network Analyst stage.

A few existing waste collection centers were identified based on the interviews.

Buttonwillow Hazardous Landfill, located in the Central Valley, is the location to which all PV waste is now sent, since there is no other facility for processing hazardous PV 
waste in California. In the state of Nevada, Apex Landfill is known as the largest landfilling site in the United States, and it is expected that some PV waste from California will be sent there.

Finally, AGOL's "Use Proximity - Find Nearest" function was used to calculate the distance between the PV waste sources and two destination types using the Trucking Distance setting: (1) the simulated collection center and (2) the two current destinations, Buttonwillow and Apex. After identifying the distances from the PV waste sources to the simulated locations, potential Greenhouse Gas (GHG) emissions from trucking the waste were estimated as an indicator for comparing the environmental impacts from reverse logistic activities. For more information regarding the mapping and the calculation of GHG, see Appendix F. 


\section{Results}

Since most of the stakeholders in California occupy positions in government agencies, firms, and organizations that do not allow them to officially comment on the record, very few were willing to be involved in the research as a formal interviewee. Only four of the 27 potential interviewees contacted participated in a formal interview (Table 1). The other thirteen interviewees participated in the interview but asked that their participation remain anonymous and their responses were only attributed to their type of stakeholder or organization. This study summarized all of the information collected from both formal and anonymous interviews in order to inform the simulation of the possible scenarios for PV waste flow and stakeholders' perspectives for EPR in California.

Table 1

Number of Potential/Actual Participating Interviewees

\begin{tabular}{lcc} 
Stakeholders & Potential interviewees & $\begin{array}{c}\text { Interviewees participating in } \\
\text { formal interview }\end{array}$ \\
\hline Manufacturer & 4 & 1 \\
Installer & 2 & \\
E-waste Recycler & 8 & 3 \\
NGO \& Local Government & 13 & $\mathbf{4}$ \\
Total & $\mathbf{2 7}$ & \\
\hline
\end{tabular}

Research Question 1: What are the photovoltaic waste flows anticipated in the San Francisco Bay Area, California?

An increase in PV waste has been noted by all of the local government officials who were interviewed over the course of this study, as well as the representatives from organizations and e-waste recycling companies (Table 2). 
Table 2

List of Participating Interviewees by Stakeholder Type

\begin{tabular}{l|l}
\hline Stakeholder type & Organization/Company \\
\hline Manufacturer & $\begin{array}{l}\text { Envision } \\
\text { First Solar }\end{array}$ \\
\hline Installer & Solar Cowboyz \\
\hline E-waste Recycler & $\begin{array}{l}\text { Napa Recycling } \\
\text { ARCOA Group }\end{array}$ \\
\hline NGO \& Local & $\begin{array}{l}\text { PV CYCLE } \\
\text { California Product Stewardship Council } \\
\text { The California Department of Resources Recycling and Recovery } \\
\text { County of Santa Cruz } \\
\text { County of Santa Clara }\end{array}$ \\
& $\begin{array}{l}\text { California Against Waste } \\
\text { The California Resource Recovery Association } \\
\text { Recycle PV Solar }\end{array}$ \\
\hline
\end{tabular}

Note. All names withheld by request.

The lone company who already developed a take-back system is working with an engineering procurement construction (EPC) company to de-install EOL modules from the installation sites. Next, all of the EOL modules will be transported to their recycling facilities, but only once the volume reaches a cost-effective price, since reverse logistics represents the largest cost during the recycling process. Nevertheless, residents often called their local governments requesting disposal of EOL PV modules, as a local government office in County of Santa Cruz pointed out:

Only work with ECS (one of the biggest e-waste recyclers) that they will come to collect the PV waste when there is a request, but they bankrupt recently, so still need to seek the other ways to process the PV waste. Due to the fact of PV waste was categorized as hazardous waste by DTSC, all the PV wastes were transported to the other states, like Texas (personal communication, August 23, 2018).

However, because there are no PV recycling facilities in California (Paben, 2018), the current solution to processing PV waste in California is to either store PV waste on-site 
or to send it to a landfill site in Nevada (Tavares, 2009) unless the companies or local governments contact the PV waste recycling company based in Arizona for further direction. In fact, there were eight stakeholders from informal interviews who pointed out that there was currently no place to process PV waste in California and thus it ends up in landfills.

\section{Research Question 2: What are stakeholders' perspectives on extended producer responsibility for photovoltaic waste?}

EPR can facilitate a boost in the PV recycling in California, especially when new legislation targets $100 \%$ renewable energy in the state. However, stakeholders like manufacturers and e-waste recyclers need to have incentives and a certain amount of flexibility before they will support the proposed legislation. Manufacturers may claim the ownership of PV waste is not their responsibility; awareness of processing PV waste is not evident among the solar industry in California. Furthermore, to develop EPR in California, the process is: first, public organizations lobby the legislator to draft the ordinance or legislation. Next, seek support from the other legislators on the proposed legislation. Then, once the governor signs the legislation for validation, the corresponding agency obtains the authorization to implement the legislation.

The interviewee from First Solar, Inc. indicated that the organization understands the toxicity of their products; therefore, they choose to prevent environmental concerns by voluntarily conducting their recycling program. According to this senior scientist at First Solar, Inc., one benefit of having the EPR program is that it can show the company's environmental awareness and product responsibility to the customers: 
...the cadmium telluride semi-conductor is the valuable material that we recover when we recycle. The second benefit of recovering that material is that it addresses some of the environmental concern about waste management with cadmium telluride... When you're developing project, and you have to convince a county planning commission that you're a responsible developer, having a recycling solution is part of that being responsible (personal communication, May 14, 2018).

The interviewee with PV CYCLE indicated that the WEEE Directive provided the legislative framework for EPR for PV on August 13, 2012, and the regulation was validated on February 14, 2014 for all the member countries in the European Union (PV CYCLE, n.d.). EPR significantly boosted the cognition of PV waste among governments and industry in Europe. Therefore, as the below quotation from the interview with Director of PV CYCLE showed, EPR has boosted the market for recycling PV waste within the European Union and helped to support the operation of PV CYCLE, closing the loop of the materials used in the PV industry for the company:

at the meantime, 2014 the legislation tapped in, so we are now under the scope of the electronic waste (Waste on Electrical and Electronic Equipment, abbreviated to WEEE) legislation in Europe. It is a good evolution ... Legislation has put the heat on the discussion to include or not the PV Panels under the WEEE Legislation at that time... So if the legislation was not there, then there is no PV CYCLE is probably not there anymore, or maybe in a kind of form we would be a knowledge or experts center (personal communication, May 9, 2018).

Since CalRecycle does not have the EPR program for PV modules and there is only one state Senator who has expressed their support in leading the effort of EPR, it is unlikely that EPR will be implemented in California in the near future. One possible reason is that building the fund for recycling program might increase the cost of installation and decrease the adoption of solar modules; preparing EPR for PV modules and this could result in lost political capital for Senators. 


\section{Research Question 3: Where are the optimal locations for collecting photovoltaic waste in the San Francisco Bay Area?}

The projected volume of PV waste in California and the San Francisco Bay Area is shown in Figure 4. Graduated symbols in ArcMap 10.6.1 were used to map the magnitude of PV waste sources in the coming years. As Figure 5 shows, after an earlyloss scenario calculation, over twenty thousand tons of PV waste will appear in the Bay Area regions by 2030; the East and South Bay regions are expected to have higher volumes of PV waste, while San Francisco and Napa County will have lower amounts.
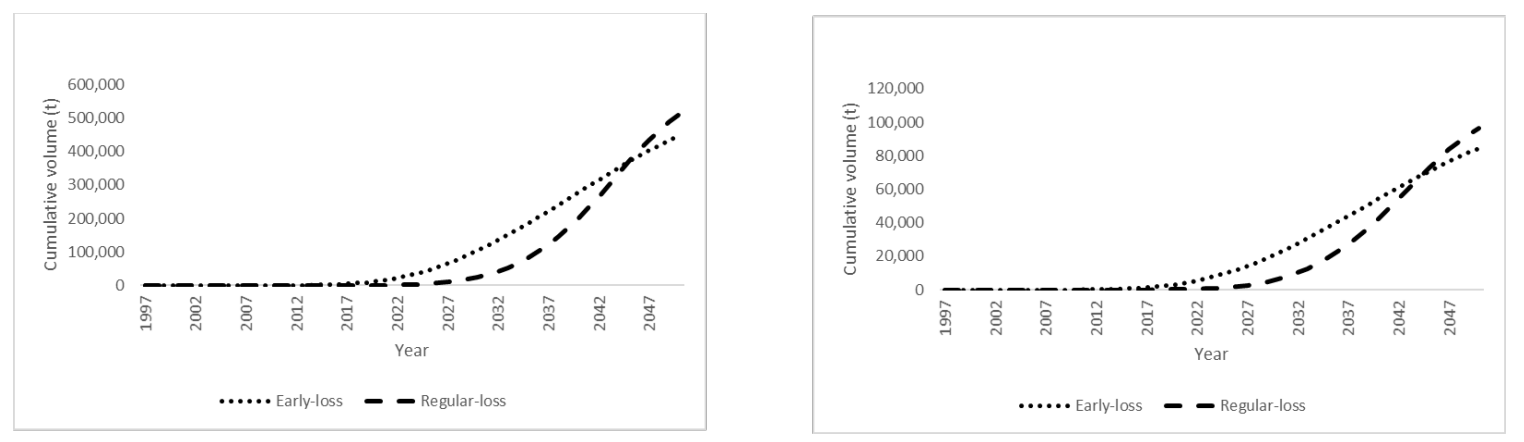

Figure 4. PV waste projections in California (left) and in the San Francisco Bay Area (right). Based on current installed PV system capacity, by the year of 2045, there will be around 400 thousand tons of PV waste in California. Note the projected PV waste volume increase in regular-loss scenario due to the probability of loss catch up when compared with the early-loss scenario after the 30 years of lifespan in PV system. 


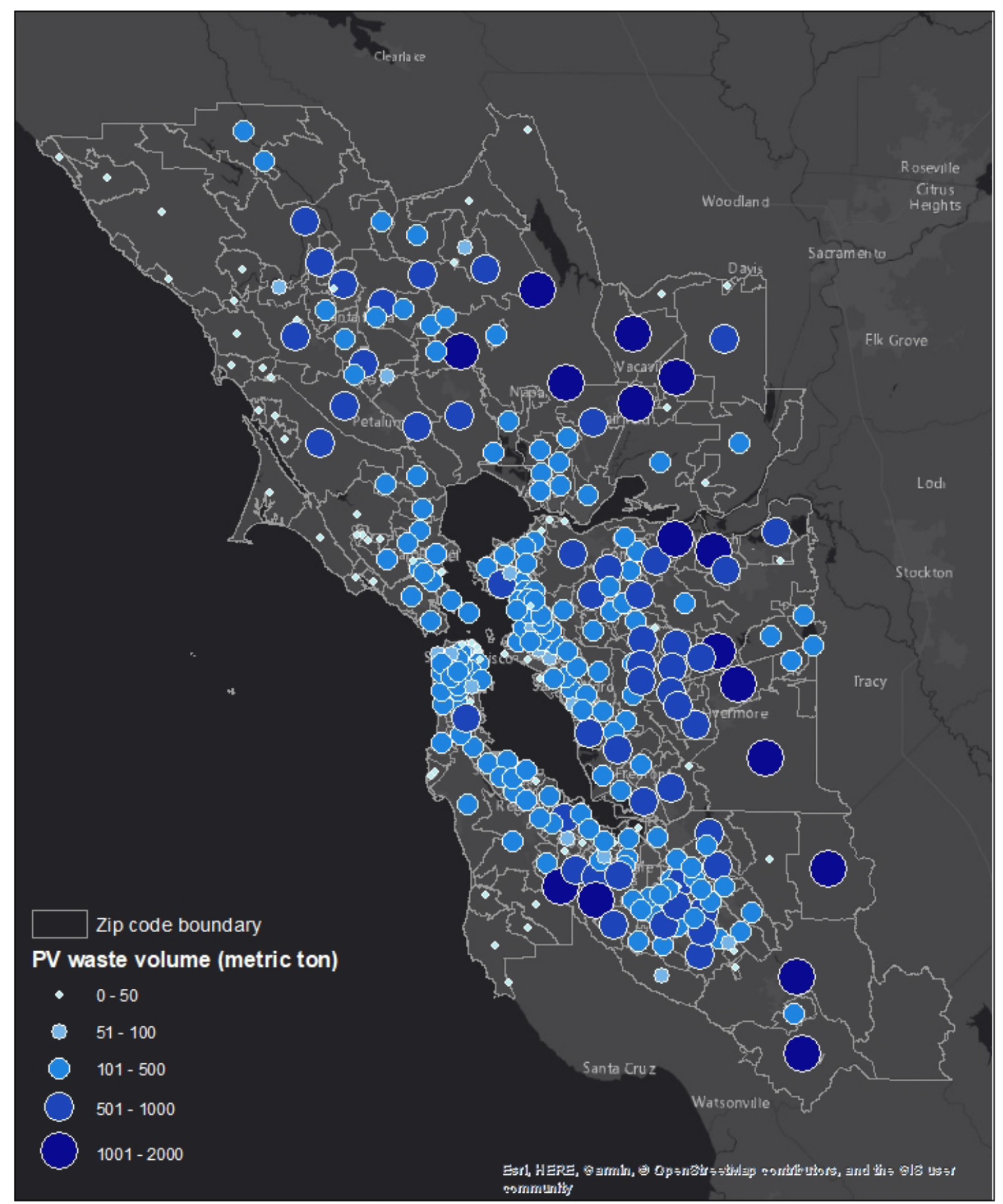

San Jose State University Map prepared by Lee-Tan Lu February 24, 2019

Figure 5. PV waste distribution in the San Francisco Bay Area under early-loss scenario by 2050 .
Data Source

mp (2009, April 13). USA Zip Code Boundaries Data. retrieved from ArcGIS REST Services Directory: https ://gis .us ps .com/arogis/rest/services/ED DM/EDDM_ZIP5/MapServer/layers

California Distributed Generation Statistics. (2019, January 8). Statistics and Charts. Retrieved from Californis Distributed Generation Statistics: https://www.californiadgstats .ca.gov

RENA ond IEA-PVPS (2010), End

Renewable Energy Agenoy and International Energy Agenoy Photovoltaic Power Sys tems. 
However, the next step of using "Analyze Patterns - Find Hot Spots" on AGOL helped to more accurately indicate areas that could have increased PV waste compared to the other regions, helping to optimize potential locations for collecting PV waste. Figure 6 shows the projected PV waste volume using Hot Spots analysis, under the early-loss scenario, by the year of 2050 . The red dots specify the areas that have statistically higher PV waste volume than the neighboring regions. In contrast to hot spots, the cold spots (blue dots) show where relatively low volume of projected PV waste will appear in 2050. 


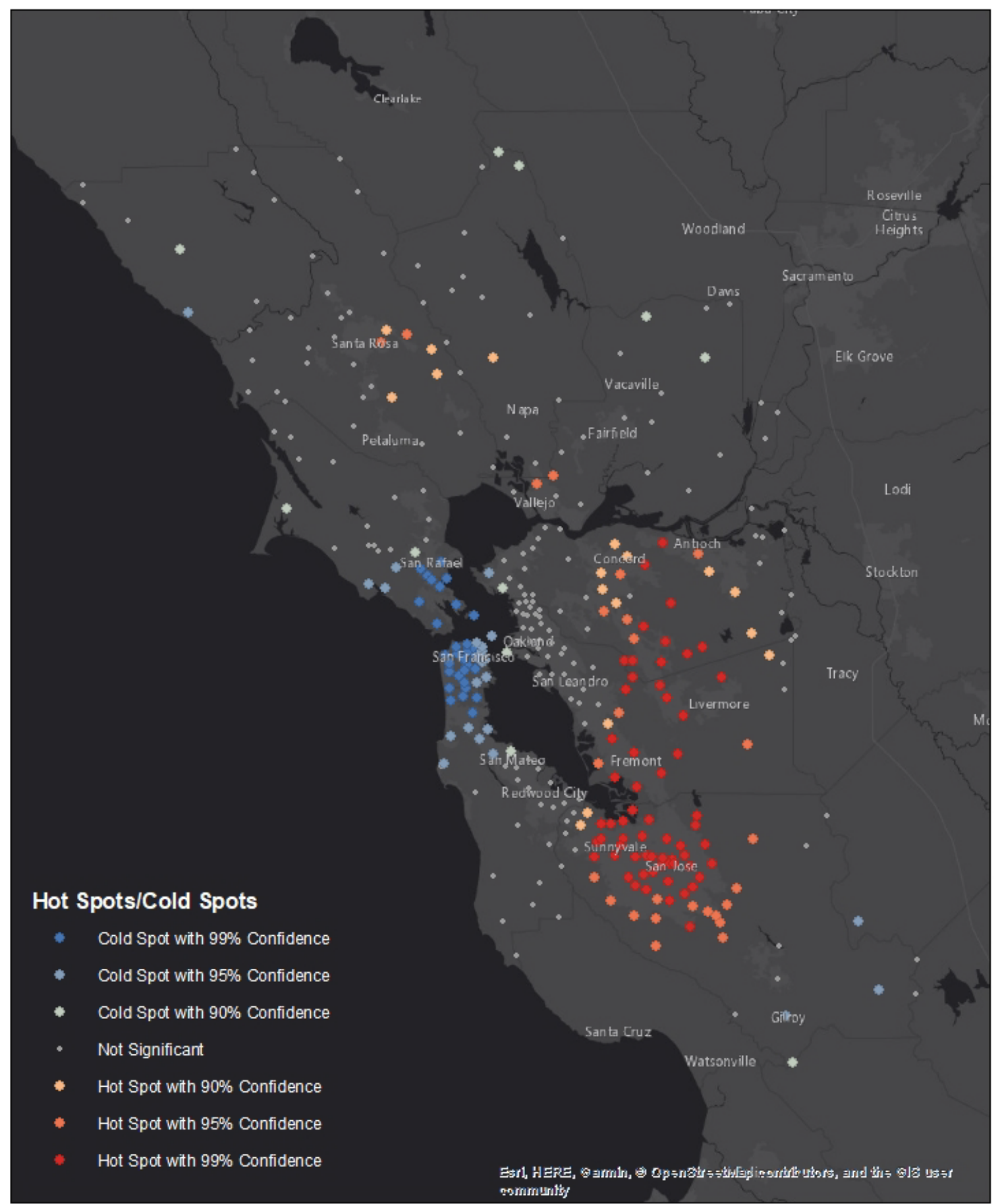

San Jose State University

Map prepared by Lee-Tan Lu

Data Source

mp (2009, April 13). USA Zip Code Boundaries Data. retrieved from ArcGIS REST Services Directory: https ://gis .us ps .com/arcgis/rest/services/EDDM/EDDM_ZIP5/MapServer/layers

California Distributed Generation Statistics. (2019, January 8). Statistics and Charts. Retrieved from California Distributed Generation Statistics: https://www.californiadgstats .ca.gov

IRENA and IEA-PVPS (2016), "End-of-Life Management: Solar Photovoltaic Panels", International

Renewable Energy Agency and International Energy Agency Photovoltaic Power Sys tems.

Figure 6. Hot spots analysis of projected PV waste volume in the San Francisco Bay Area under early-loss scenario by 2050 . 
After using AGOL's “Use Proximity - Find Nearest” function, the optimal locations for collecting PV waste were sited based on different scenarios (Table 3). If a single collection center is set up in the region that encompasses the North, East, and South Bay, the average distance from the waste sources to the center will be 38.9 miles. If two collection centers are set up in the same region, the average distance will be 32.7 miles, and with three collection centers, the average distance will be 20.7 miles. By comparison, the average distance from the waste sources to Buttonwillow Hazardous Landfill in the Central Valley is 240.1 miles, and to the Apex Landfill in Nevada is 578.8 miles.

Table 3

Average Distance from PV Waste Sources to the Optimal Collection Centers and Generated Greenhouse Gas (GHG) Emissions

\begin{tabular}{|c|c|c|c|c|}
\hline Scenario & Region & $\begin{array}{c}\text { Average } \\
\text { Distance } \\
\text { (miles) }\end{array}$ & $\begin{array}{c}\text { Overall } \\
\text { Average } \\
\text { Distance } \\
\text { (miles) }\end{array}$ & $\begin{array}{c}\text { GHG } \\
\text { Emission } \\
(\text { kgCO2eq) }\end{array}$ \\
\hline 1 collection center & North, East, South Bay & 38.9 & 38.9 & 100.2 \\
\hline $\begin{array}{l}2 \text { collection } \\
\text { centers }\end{array}$ & $\begin{array}{l}\text { North, East Bay } \\
\text { East, South Bay }\end{array}$ & $\begin{array}{l}38.8 \\
26.6\end{array}$ & 32.7 & 84.2 \\
\hline $\begin{array}{l}3 \text { collection } \\
\text { centers }\end{array}$ & $\begin{array}{l}\text { North Bay } \\
\text { East Bay } \\
\text { South Bay }\end{array}$ & $\begin{array}{l}25.3 \\
25.8 \\
11.0\end{array}$ & 20.7 & 51.5 \\
\hline $\begin{array}{l}\text { Landfill } \\
\text { (California) }\end{array}$ & $\begin{array}{l}\text { Buttonwillow } \\
\text { Hazardous Landfill } \\
\text { (Central Valley) }\end{array}$ & 240.1 & 240.1 & 618.5 \\
\hline $\begin{array}{l}\text { Landfill } \\
\text { (Nevada) }\end{array}$ & Apex Landfill & 578.8 & 578.8 & 1491 \\
\hline
\end{tabular}

Notably, a 30-fold increase in potential GHG emissions can be expected by transporting PV waste all the way to the Apex Landfill as opposed to local San Francisco 
Bay Area collection sites (Figure 7). The simulated collection network with three collection sites can be seen in Figure 8. With the consideration of finding the nearest route from the sources of the PV waste to the collection center, one can shorten the distance for reverse logistics, also generating fewer GHG emissions than the other scenarios.

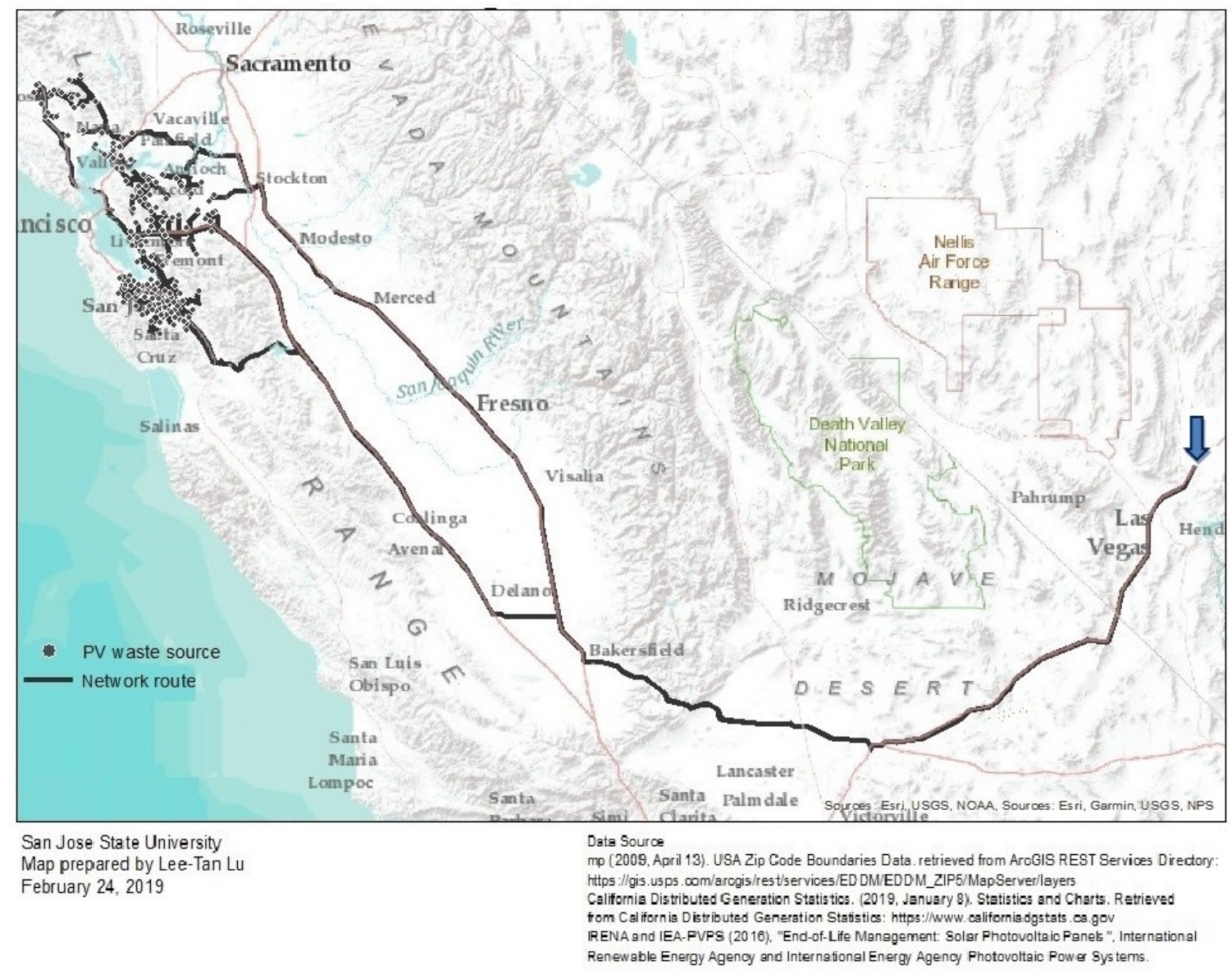

Figure 7. Simulated PV waste flow from San Francisco Bay Area to Apex Landfill in Nevada. The blue arrow on the map is the location of Apex Landfill site. 


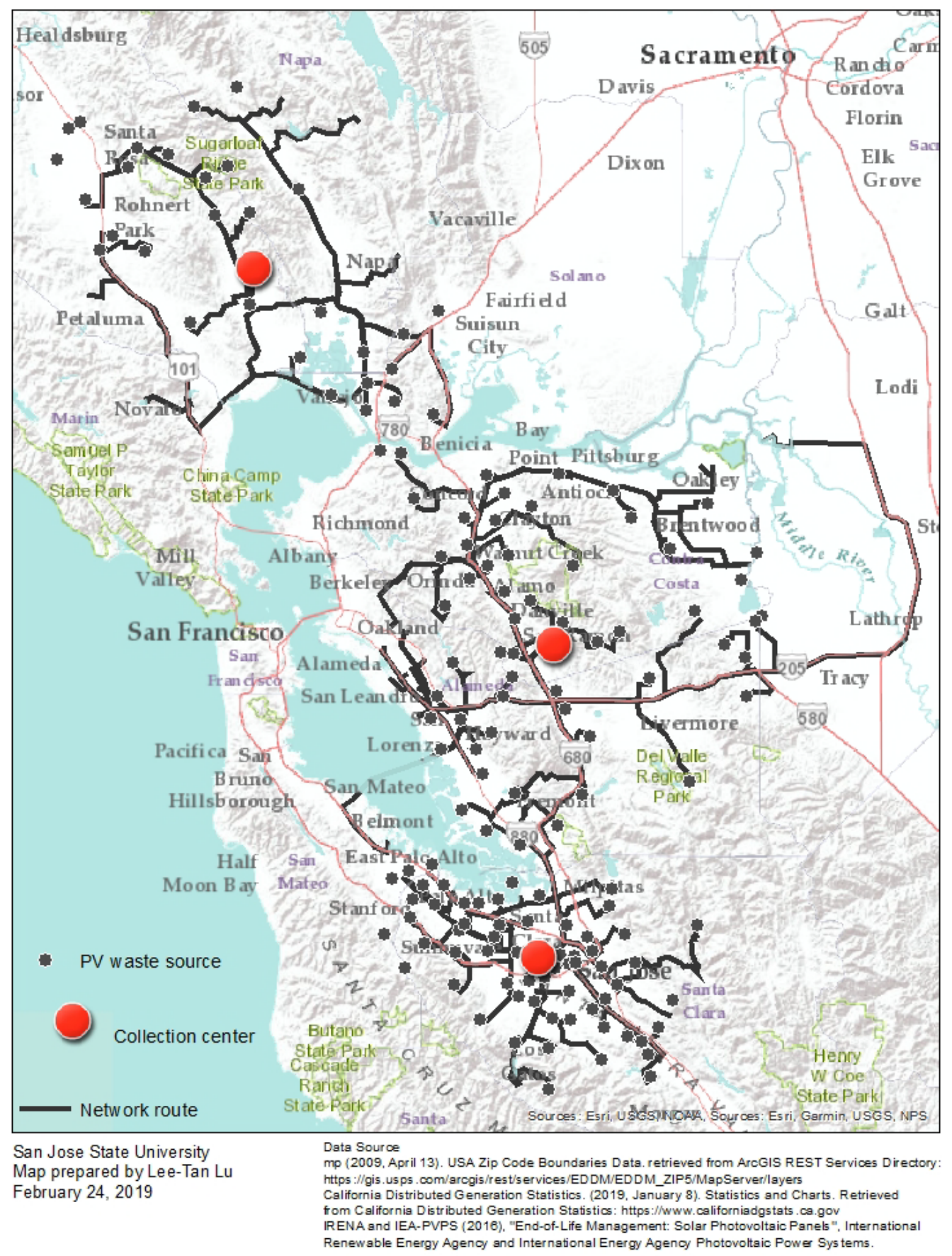

Figure 8. Simulated PV waste collection network with three collection centers in the San Francisco Bay Area. 


\section{Discussion}

Currently, the proposed PV waste management regulation by DTSC in California involves categorizing the portion of PV waste that passes over the threshold of hazardous waste into universal waste (California Department of Toxic Substances Control, n.d. ${ }^{\text {b) }}$. Although categorization as universal waste could help to divert this portion of PV waste from the hazardous waste stream, it does not help develop a solution for processing PV waste within the state. A disposal fee incurred by public and local governments is likely to increase the cost of reverse logistics for transporting the PV waste into other regions. Additionally, this modification does not make manufacturers consider the environmental impact of their production, nor does it incentivize them to consider how to recycle materials through their production systems. Contrary to categorizing some PV waste as universal waste, the EPR program can have an influence on production both upstream and downstream within the industry.

Interestingly, over $85 \%$ of the interviewees in this study were not in the solar industry (24 out of 27 interviewees). However, awareness of PV waste among local governments and NGOs could be the main factor in developing legislation for PV waste management. For example, local governments could require manufacturers and other stakeholders to provide collection and recycling schemes, diverting the burden from the public sector to eventually clean up the waste. On the other hand, the lack of interview participants from the solar industry supply chain demonstrates the current state of the market: the market for recycling PV waste in California is virtually non-existent, since building an effective collection and recycling plan would require additional stakeholder investment. If 
manufacturers are asked to fund an EPR program, it is possible that the imposed cost might be added on to the price of PV modules in California.

Besides having a manufacturer-funded collection and recycling program, which could affect the transition to renewable electricity sources, there are many other economic factors which could have an impact. Since 2010, both President Obama and President Trump have set Section 201 and Section $301^{1}$ tariffs on imported solar panels to protect domestic solar panel production (Eckhouse, Natter, \& Martin, 2018; Office of the United States Trade Representative, 2010; Pyper, 2018). These actions could increase the shortterm price of imported solar installation, but the long-term impacts are unclear (Aggarwal, 2018).

Another factor that might affect the electricity prices for renewable sources is the net metering system. Pacific Gas and Electric (PG\&E), the primary electricity service provider in the San Francisco Bay Area, was suspected as the cause of the Camp Fire in December 2018, and as a result they filed bankruptcy protection in January 2019 (Roth, 2019). It is likely that this incident will increase electricity prices, including the price of electricity derived from PV modules in California. The current amount of the debt that PG\&E has will depend on the court's pending decision, and if they are not allowed to reduce their debt obligation, it is possible that PG\&E will increase electricity prices, pending approval by the California Public Utilities Commission (Rogers, 2019). Furthermore, a few long-term contracts signed between PG\&E and solar or wind farms

\footnotetext{
${ }^{1}$ Since the majority of the PV modules were imported from China, U.S. President Trump used Section 201 of the U.S Trade Act as the instrument to temporarily limit the imported goods once the identified domestic industries are threatened; U.S. President Obama used Section 301 to targeted unfair foreign trade practices (Gertz, 2018; Office of the United States Trade Representative, 2010).
} 
may be nullified by the bankruptcy judge (Rogers, 2019), to boost the profitability of the company so that it may pay damages to those who suffered losses in the fires. Thus, the EPR program and setting up collection sites for PV waste might be postponed by the legislators due to their limited political capital with regards to achieving renewable targets and developing EPR.

Under the linear economy model, it is anticipated that the extraction of raw materials will become more expensive and will accelerate environmental degradation (Ellen MacArthur Foundation and McKinsey \& Company, 2014). As a result, balancing the installation price of PV modules and the potential costs from implementing an EPR program requires additional engagement and discussion between stakeholders and the government (Wade, 2018). This engagement might mean adjusting the proposed regulation to allow certain e-waste recyclers to process PV waste, incentivizing manufacturers to collect their EOL products, encouraging improved recycling technology to recover materials, and promoting the importance of sovereign material independence.

The current regulations for PV waste management in California might curtail the evolution of the recycling market and sovereign material independence, especially when it forbids PV waste collection and processing. By 2030 in the San Francisco Bay Area, certain counties will be impacted first by expected PV waste increases, including Santa Clara, Alameda, and Contra Costa counties. According to the results that illustrate the current and future potential PV waste collection centers, transporting PV waste from the San Francisco Bay Area to other states not only incurs a large cost but also generates at least 30 times more GHG emissions. However, when comparing between centralized and 
decentralized collection centers in the San Francisco Bay Area, decentralized collection centers could reduce transportation costs and create less GHG emissions. The optimized locations in this study may not be the most practical sites, and more data are needed in order to improve the reverse logistics network which accounts for the transportation costs of PV waste, operation costs of the collection and recycling facilities, labor costs, material demand, zoning, environmental and construction permits, and so on. Adjusting the policy scheme for PV waste management appears to be the first step to help to increase the awareness of the PV waste issue in California. 


\section{Conclusions and Recommendations}

California has invested significantly in accelerating solar energy adoption and has the largest PV system capacity in the United States (U.S. Energy Information Administration, 2016). However, the limited lifespan of PV modules will result in an enormous amount of waste released into the environment, about 90 thousand tons by 2050 in the San Francisco Bay Area alone. Based on the findings in this study, there is no clear pathway in California to process PV waste, with the possible exception of sending it to a hazardous waste landfill or exporting it to another state or nation. Both of those outcomes are suboptimal: whether exporting the PV waste to another state or country or processing it as waste in a hazardous waste landfill in California, either outcome creates new sets of environmental and economic challenges. EPR could encourage the industry to redesign products to make less waste and include more recycled content from the outset, closing the materials loop and moving society towards a sustainable environment.

Even though the amount of PV waste is currently not large enough to attract recyclers or manufacturers to collect and recover the materials, it would be advisable for both legislation and the take-back system to get proactively developed before the large quantity of PV waste emerges in the state over the next decade. Legislation and collection programs can reduce the amount of waste sent into landfill. Industry may choose to collect and process discarded PV modules, as First Solar does. Such voluntary recycling approaches can be flexible for stakeholders, however, without the support of legislation, collaboration could be difficult due to the economics and the liability issues. Having an EPR program for PV waste in California would complement the global trend of e-waste 
recycling and corporate responsibility (Khetriwal, Kraeuchi, \& Widmer, 2009).

California is the state with the highest installation volume of PV modules and one of the most ambitious renewable energy adoption goals in the nation. It would thus be the responsible thing for California to close this open loop of consumption by acting to establish an EPR program. As of May 2018, a new mandate from the California Energy Commission requires that new houses built after 2020 in California to install solar modules on their rooftops (Chappell, 2018). This will result in more widely distributed solar module systems in California despite no planned update to the waste collection system. Thus, it is important to consider having the EPR program in order to facilitate the creation of a market for PV waste collection.

The main challenges of collecting PV waste, or e-waste, in California are similar to those of the other regions in the world: lack of awareness of the increasing amount of waste; lack of voluntary recycling by stakeholders; lack of communication and understanding between stakeholders; lack of neutral monitors and/or enforcement, and lack of infrastructure, including a collection system, to process the waste (Quoden, 2018; Tansel, 2017). Additionally, there are political obstacles when it comes to establishing EPR for PV waste. The public's awareness of what they can do in order to influence legislators, especially when building legislation, becomes essential. Accumulative small efforts by NGOs and local governments can create an impact on the industry and related shareholders.

This study provides background information for understanding the general PV waste management landscape in California, stakeholders' perspectives on having an EPR 
program for solar modules, and the potential GHG emissions associated with different scenarios for collecting PV waste in the San Francisco Bay Area. Greater cognizance among stakeholders of the increasing amount of PV waste is required for building a more comprehensive EPR program that is better suited for California, either voluntarily or involuntarily. Future studies could compare the different EPR programs with those of European countries, as well as other states, such as Washington State and New York, in order to hone in on a suitable program for California. Also, future studies could consider related equipment used in the operation of $\mathrm{PV}$, such as batteries. As for estimating the number and location of possible collection centers in the San Francisco Bay Area specifically or in California at large, more parameters should be included to make the model more comprehensive, such as the expenses of opting for PV waste recycling plants at different scales; the average of labor and transportation costs in California for hazardous waste; local zoning ordinances; environmental impacts from the different types of vehicles from reverse logistics; and environmental justice issues facing neighborhoods around recycling facilities (Fimrite, 2019). To achieve a sustainable future, new technology must be adopted to decrease dependence on nonrenewable energy, and in a linear economy, with that adoption comes increasing waste streams; a circular economic model such as EPR will be an important tool to achieve this sustainable future while mitigating or even eliminating waste altogether from the product lifecycle. 


\section{References}

Acar, A. Z., Onden, I., \& Kara, K. (2015). Evaluating the location of regional return centers in reverse logistics through integration of GIS, AHP and integer programming. International Journal of Industrial Engineering, 22(4), 399-411.

Aggarwal, V. (2018, December 27). How the 2018 U.S. solar tariff will impact the price you pay. EnergySage. Retrieved from https://news.energysage.com/2018-us-solartariff-impact-prices/

Balde, C. P., Wang, F., Kuehr, R., \& J, H. (2015). The global e-waste monitor 2014. Bonn: United Nations University \& IAS -- SCYCLE. http://i.unu.edu/media/unu.edu/news/52624/UNU-1stGlobal-E-Waste-Monitor2014-small.pdf

Besiou, M., \& Wassenhove, L. N. (2015). Closed-loop supply chains for photovoltaic panels. Journal of Industrial Ecology, 20, 929-937.

Breyer, C., Koskinen, O., \& Blechinger, P. (2015). Profitable climate change mitigation: The case of greenhouse gas emission reduction benefits enabled by solar photovoltaic system. Renewable and Sustainable Energy Reviews, 49, 610-628.

California Department of Toxic Substances Control. (n.d. ${ }^{a}$ ). Electronic hazardous waste (e-waste). Retrieved from https://dtsc.ca.gov/ewaste/electronic-hazardous-wastee-waste/

California Department of Toxic Substances Control. (n.d. ${ }^{\mathrm{b}}$ ). Photovoltaic modules (PV modules): Universal waste management regulations. Retrieved from https://dtsc.ca.gov/photovoltaic-modules-pv-modules-universal-wastemanagement-regulations/

California Distributed Generation Statistics. (n.d.). Download data. Energy Solutions. Retrieved October 31, 2018 from https://www.californiadgstats.ca.gov/downloads/

California ISO. (2017, June 19). What are we doing to green the grid? California Independent System Operator. Retrieved from http://www.caiso.com/informed/Pages/CleanGrid/default.aspx

California Legislative Information. (2015, October 1). SB-489 Hazardous waste: Photovoltaic modules. Retrieved from https://leginfo.legislature.ca.gov/faces/billNavClient.xhtml?bill_id=201520160SB 489 
California Legislative Information. (2018, September 10). SB-100 California renewables portfolio standard program: Emissions of greenhouse gases. Retrieved from https://leginfo.legislature.ca.gov/faces/billNavClient.xhtml?bill_id=201720180SB 100

California Product Stewardship Council. (n.d.). Products. Retrieved from https://www.calpsc.org/products

CalRecycle. (n.d. $\left.{ }^{a}\right)$. Product stewardship and extended producer responsibility (EPR). Retrieved from CalRecycle: http://www.calrecycle.ca.gov/epr/

CalRecycle. (n.d. b). National Sword and China's restriction on the import of recyclable material. Retrieved October 23, 2018 from https://www.calrecycle.ca.gov/Markets/NationalSword/

Chappell, B. (2018, December 6). California gives final OK to require solar panels on new houses. Retrieved from npr: https://www.npr.org/2018/12/06/674075032/california-gives-final-ok-torequiring-solar-panels-on-new-houses

Choi, J. K., \& Fthenakis, V. $\left(2010^{\mathrm{a}}\right)$. Design and optimization of photovoltaics recycling infrastructure. Environmental Science \& Technology, 44, 8678-8683

Choi, J. K., \& Fthenakis, V. $\left(2010^{\mathrm{b}}\right)$. Economic feasibility of recycling photovoltaic modules. Journal of industrial Ecology, 14, 947-964.

Choi, J. K., \& Fthenakis, V. (2014). Crystalline silicon photovoltaic recycling planning: macro and micro perspectives. Journal of Cleaner Production, 66, 443-449.

Dobbs, R., Oppenheim, J., Thompson, F., Mareels, S., Nyquist, S., \& Sanghvi, S. (2013, September). Resource revolution: Tracking global commodity markets. McKinsey \& Company. Retrieved from https://www.mckinsey.com/businessfunctions/sustainability/our-insights/resource-revolution-tracking-globalcommodity-markets

Eberspacher, C., \& Fthenakis, V. (1997). Disposal and recycling of end-of-life PV modules. Proceedings of the Twenty Sixth IEEE Photovoltaic Specialists Conference - 1997, 1067-1072.

Eckhouse, B., Natter, A., \& Martin, C. (2018, January 22). President Trump slaps tariffs on solar panels in major blow to renewable energy. Time USA, LLC. Retrieved from http://time.com/5113472/donald-trump-solar-panel-tariff/

ECS Refining. (n.d.). Hazardous \& industrial waste. Retrieved from ECS Refining: https://www.ecsrefining.com 
Ellen MacArthur Foundation. (2012, January 25). Towards the circular economy vol. 1: An economic and business rationale for an accelerated transition. United Kingdom. Retrieved from https://www.ellenmacarthurfoundation.org/publications/towards-the-circulareconomy-vol-1-an-economic-and-business-rationale-for-an-accelerated-transition

Ellen MacArthur Foundation. (2013, January 25). Towards the circular economy vol. 2: Opportunities for the consumer goods sector. United Kingdom. Retrieved from https://www.ellenmacarthurfoundation.org/assets/downloads/publications/TCE_R eport-2013.pdf

Ellen MacArthur Foundation and McKinsey \& Company. (2014). Towards the circular economy: Accelerating the scale-up across global supply chains. Geneva: World Economic Forum.

http://www3.weforum.org/docs/WEF_ENV_TowardsCircularEconomy_Report_2 014.pdf

Elliott, B. (2018, April 26). ECS Refining seeks Chapter 11 protection. Resource Recycling, Inc. Retrieved from https://resource-recycling.com/escrap/2018/04/26/ecs-refining-seeks-chapter-11-protection/

EnergySage. (2017, September 6). What are the top solar panel manufacturers in the USA? Retrieved from https://news.energysage.com/best-solar-panelmanufacturers-usa/

EPA Resource Conservation and Recovery Act (RCRA) Regulations. (n.d.). Identification and listing of hazardous waste. Retrieved from https://www.epa.gov/rcra

e-Stewards. (n.d.). Find a Recycler. Retrieved from http://e-stewards.org/find-a-recycler/

European Commission - DG Environment. (2014). Development of guidance on extended producer responsibility (EPR). Neuilly-sur-Seine: Bio by Deloitte. http://ec.europa.eu/environment/waste/pdf/target_review/Guidance\%200n\%20EP R\%20-\%20Final\%20Report.pdf

Fimrite, P. (2019, March 8). Diesel trucks would be nearly eliminated in California under proposed law. San Francisco Chronicle. Retrieved from https://www.sfchronicle.com/science/article/Diesel-trucks-would-be-nearlyeliminated-in-13674820.php

First Solar. (n.d.). Modules: Recycling. [Webpage] Retrieved from http://www.firstsolar.com/en/Modules/Recycling 
Geissdoerfer, M., Savaget, P., Bocken, N. M., \& Hultink, E. J. (2017). The circular economy -- A new sustainability paradigm? Journal of Cleaner Production, 143, $757-768$.

Georgescu-Roegen, N. (1971). The entropy law and the economic process. Cambridge, MA: Harvard University Press.

Gertz, G. (2018, February 16). Is Trump remaking American trade enforcement policy? The Brookings Institution. Retrieved from https://www.brookings.edu/blog/future-development/2018/02/16/is-trumpremaking-american-trade-enforcement-policy/

Gibson, T. L., \& Kelly, N. A. (2010). Solar photovoltaic charging of lithium-ion batteries. Journal of Power Sources, 195, 3928-3932.

Gu, F., Guo, J., Yao, X., Summers, P. A., Widijatmoko, S. D., \& Hall, P. (2017). An investigation of the current status of recycling spent lithium-ion batteries from consumer electronics in China. Journal of Cleaner Production, 161, 765-780.

Guide Jr., V. D., Harrison, T. P., \& Wassenhove, L. N. (2003). The challenge of closedloop supply chains. Interfaces, 33, 3-6.

Hendrickson, T. P., Kavvada, O., Shah, N., Sathre, R., \& Scown, C. D. (2015). Life-cycle implications and supply chain logistics of electric vehicle battery recycling in California. Environmental Research Letters. https://iopscience.iop.org/article/10.1088/1748-9326/10/1/014011/pdf

Holowka, T. (2017, April 5). Top four benefits of installing solar panels on your home. U.S. Green Building Council - Long Island Chapter. Retrieved from https://usgbc-li.org/content/top-four-benefits-installing-solar-panels-your-home

Hoornweg, D., Bhada-Tata, P., \& Kennedy, C. (2013). Environment: Waste production must peak this century. Nature, 502, 615 .

https://www.nature.com/news/environment-waste-production-must-peak-thiscentury-1.14032

Hossain, M. S., Al-Hamadani, S. M., \& Rahman, M. T. (2015). E-waste: A challenge for sustainable development. Journal of Health \& Pollution, 5, 3-11.

Hossain, S., Sulatan, S., Shahnaz, F., Akram, A. B., Nesa, M., \& Happell, J. (2010). Study on e-waste: Bangladesh situation. Dhaka: Environmental and Social Development Organization-ESDO.

IRENA \& IEA-PVPS. (2016). End-of-Life Management: Solar photovoltaic panels. [Joint report]. 
Kahhat, R., Kim, J., Xu, M., Allenby, B., Williams, E., \& Zhang, P. (2008). Exploring ewaste management systems in the United States. Resources, Conservation and Recycling, 52, 955-964.

Kang, H. Y., \& Schoenung, J. M. (2005). Electronic waste recycling: A review of U.S. infrastructure and technology options. Resources Conservation \& Recycling, 45, $368-400$.

Khan, S. S., Lodhi, S. A., Akhtar, F., \& Khokar, I. (2014). Challenges of waste of electric and electronic equipment (WEEE): Toward a better management in a global scenario. Management of Environmental Quality: An International Journal, 25, 166-185.

Khetriwal, D. S., Kraeuchi, P., \& Widmer, R. (2009). Producer responsibility for e-waste management: Key issues for consideration -- Learning from the Swiss experience. Journal of Environmental Management, 90, 153 - 165.

Kiddee, P., Naidu, R., \& Wong, M. H. (2013). Electronic waste management approaches: An overview. Waste Management, 33, 1237-1250.

Lewis, R. B. (2004). NVivo 2.0 and ATLAS.ti 5.0: A comparative review of two popular qualitative data-analysis programs. Field Methods, 16(4), 439-464.

Li, J., Lopez N, B. N., Liu, L., Zhao, N., Yu, K., \& Zheng, L. (2013). Regional or global WEEE recycling. Where to go? Waste Management, 33, 923-934.

Li, L., Zhai, L., Zhang, X., Lu, J., Chen, R., Wu, F., \& Amine, K. (2014). Recovery of valuable metals from spent lithium-ion batteries by ultrasonic-assisted leaching process. Journal of Power Sources, 262, 380-385.

Lieder, M., \& Rashid, A. (2016). Towards circular economy implementation: a comprehensive review in context of manufacturing industry. Journal of Cleaner Production, 115, 36-51.

Marwede, M., Berger, W., Schlummer, M., Mäurer, A., \& Reller, A. (2013). Recycling paths for thin-film chalcogenide photovoltaic waste - Current feasible processes. Renewable Energy, 55, 220-229.

McLamb, E. (2011, September 6). Fossil fuels vs. renewable energy resources: Energy's future today. Ecology Communications Group, Inc. Retrieved from http://www.ecology.com/2011/09/06/fossil-fuels-renewable-energy-resources/

Moskowitz, P., \& Zweibel, K. (1992). Recycling of cadmium and selenium from photovoltaic modules and manufacturing wastes: A workshop report. United States. https://www.osti.gov/biblio/10103235 
Moss, R., Tzimas, E., Kara, H., Willis, P., \& Kooroshy, J. (2014). Critical metals in strategic energy technologies: Assessing rare metals as supply-chain bottlenecks in low-carbon energy technologies. (EUR (Luxembourg), 24884). Luxembourg: Publications Office. https://publications.europa.eu/en/publication-detail//publication/2239d6b7-cda8-4570-a9f0-13ad60ce3fl1/language-en

Nace, T. (2017, August 1). California goes all in -- 100\% Renewable energy by 2045. Forbes, Inc. Retrieved from https://www.forbes.com/sites/trevornace/2017/08/01/california-goes-all-in-100percent-renewable-energy-by-2045/

O'Mara, T. F. (2018, June 13). Senate unanimously approves O'Mara's 'Solar Panel Collection Act': O'Mara says action offers a commonsense approach to waste management. New York Senate. Retrieved from https://www.nysenate.gov/newsroom/articles/thomas-f-omara/senateunanimously-approves-omaras-solar-panel-collection-act-omara

Nixon, H., Saphores, J., Ogunseitan, O., \& Shapiro, A. (2007). Electronic waste recycling preferences in California: The role of environmental attitudes and behaviors. Proceedings of the 2007 IEEE International Symposium on Electronics and the Environment, 251-256.

Noda et al., (2014). Development of the PV recycling system for various kinds of PV modules. Proceedings of the 6th World Conference on Photovoltaic Energy Conversion in Kyoto, Japan. 23-27.

Organisation for Economic Co-operation and Development. (n.d.). Extended producer responsibility. Retrieved from http://www.oecd.org/env/toolsevaluation/extendedproducerresponsibility.htm

Organisation for Economic Co-operation and Development. (2001). Extended producer responsibility: A guidance manual for governments. Paris.

Office of the United States Trade Representative. (2010, October 15). United States launches section 301 investigation into China's policies affecting trade and investment in green technologies. Retrieved from https:/ustr.gov/about-us/policyoffices/press-office/press-releases/2010/october/united-states-launches-section301-investigation-c

Ohno, H., Matsubae, K., Nakajima, K., Nakamura, S., \& Nagasaka, T. (2014). Unintentional flow of alloying elements in steel during recycling of end-of-life vehicles. Journal of Industrial Ecology, 18, 242-253. 
Paben, J. (2018, July 3). ECS refining goes out of business. Resource Recycling, Inc. Retrieved from https://resource-recycling.com/e-scrap/2018/07/03/ecs-refininggoes-out-of-business/

PV CYCLE. (n.d.). Click on your country. [Interactive map]. Retrieved from http://www.pvcycle.org/

PV CYCLE. (2013, September 24). UK environment agency approves PV scheme. Retrieved from http://www.pvcycle.org.uk/press/uk-environment-agencyapproves-pv-scheme/

Pyper, J. (2018, January 22). Trump administration issues 30\% solar panel import tariff. Green Tech Media. Retrieved from https://www.greentechmedia.com/articles/read/breaking-trump-admin-issues-a30-solar-tariff

Quoden, J. (2018, October 31). Global best practices: Packaging EPR's role in advancing the circular economy. Product Stewardship Institute. [Webinar]. Retrieved from https://www.productstewardship.us

RecycleStuff.org. (n.d.). [Company search]. Retrieved from http://www.recyclestuff.org

Reykdal, A. (2017, July 18). First solar product stewardship law passed in Washington State. Northwest Product Stewardship Council. Retrieved from http://productstewardship.net/news/first-solar-product-stewardship-law-passedwashington-state

Rogers, P. (2019, January 15). PG\&E bankruptcy $Q \& A$ : What does it mean for me? The Mercury News. Retrieved from https://www.mercurynews.com/2019/01/14/pgebankruptcy-qa-what-does-it-mean-for-me/

Roth, S. (2019, January 29). PG\&E files for bankruptcy. Here's why that could mean bigger electricity bills. Los Angeles Times. Retrieved from https://www.latimes.com/business/la-fi-pge-bankruptcy-filing-20190129story.html

Saavedra, Y. M., Iritani, D. R., Pavan, A. L., \& Ometto, A. R. (2018). Theoretical contribution of industrial ecology to circular economy. Journal of Cleaner Production, 170, 1514-1522.

Salhofer, S., Steuer, B., Ramusch, R., \& Beigl, P. (2016). WEEE management in Europe and China - A comparison. Waste Management, 57, 27-35.

Silicon Valley Toxics Coalition. (n.d.). Solar Scorecard 2016-17. Retrieved from http://www.solarscorecard.com/2016-17/ 
Solar Energy Industries Association. (n.d.). PV recycling. Retrieved from https://www.seia.org

Solar Power World. (2016). 2016 Top California solar contractors. Retrieved from https://www.solarpowerworldonline.com/2016-top-california-solar-contractors/

Solar Waste. (n.d.). European WEEE Directive: PV waste \& legislation. PV CYCLE. Retrieved from http://www.solarwaste.eu/pv-waste-legislation/

Stiftung EAR. (n.d.). National register for waste electric equipment. Retrieved from https://www.stiftung-ear.de/en/

Tansel, B. (2017). From electronic consumer products to e-wastes: Global outlook, waste quantities, recycling challenges. Environmental International, 98, 35-45.

Tao, J., \& Yu, S. (2015). Review on feasible recycling pathways and technologies of solar photovoltaic modules. Solar Energy Materials \& Solar Cells, 141, 108-124.

Tavares, S. (2009, December 7). Mountains of garbage: Southern Nevada landfill is nation's largest. Las Vegas Sun. Retrieved from https://lasvegassun.com/news/2009/dec/07/mountains-garbage/

The Evening Tribune staff. (2018, December 14). O'Mara pushes product stewardship bills. Gatehouse Media, LLC. Retrieved from https://www.eveningtribune.com/news/20181214/strongomara-pushes-productstewardship-billsstrong

U.S. Environmental Protection Agency. (n.d.). Resources and guidance documents for compliance monitoring. Retrieved from https://www.epa.gov

U.S. Department of Defense. (2018). Assessing and strengthening the manufacturing and defense industrial base and supply chain resiliency of the United States. [Interagency Task Force report].

U.S. Energy Information Administration. (2016, February 5). Today in energy: California has nearly half of the nation's solar electricity generating capacity. [Blog post] Retrieved from https://www.eia.gov/todayinenergy/detail.php?id=24852

U.S. Energy Information Administration. (2017, June 1). Renewable energy explained. Retrieved from https://www.eia.gov

U.S. Geological Survey. (2018). Mineral commodity summaries 2018. [Annual report]. Retrieved from https://doi.org/10.3133/70194932 
van Buren, N., Demmers, M., van der Heijden, R., \& Witlox, F. (2016). Towards a circular economy: The role of Dutch logistics industries and governments. Sustainability, 8(7), 647.

Wade, A. (2018, March 15). Environmental footprint task force. Solar Power Europe. Retrieved from http://www.solarpowereurope.org/wpcontent/uploads/2018/08/Environmental-Footpring-Task-Force-Andreas-WadeFirst-Solar.pdf

Yang, J., Lu, B., \& Xu, C. (2008). WEEE flow and mitigating measures in China. Waste Management, 28(9), 1589-1597.

Zeng, X., Duan, H., Wang, F., \& Li, J. (2017). Examining environmental management of e-waste: China's experience and lessons. Renewable and Sustainable Energy Reviews, 72, 1076-1082.

Zipp, K. (2015, June 11). Solar storage charging up. Solar Power World. Retrieved from https://www.solarpowerworldonline.com/2015/06/solar-storage-charging-up/

Zuser, \& Rechberger. (2011). Considerations of resource availability in technology development strategies: The case study of photovoltaics. Resources, Conservation \& Recycling, 56(1), 56-65. 


\section{Appendices}

\section{Appendix A: Interview Questions}

Research focus area and correspond interview questions

\begin{tabular}{|c|c|c|}
\hline Focus area & Stakeholder & Question \\
\hline \multirow[t]{7}{*}{ PV waste flow } & \multirow[t]{5}{*}{ Manufacturer } & $\begin{array}{l}\text { Does _company name_consider repairing/ } \\
\text { refurbishing EOL PV for resale? What about scraps } \\
\text { from manufacturing process? }\end{array}$ \\
\hline & & $\begin{array}{l}\text { How does _ company name_ manage EOL PV } \\
\text { waste? How does the company manage PV modules } \\
\text { that become waste before they are sold } \\
\text { (manufacturing waste from failed or broken } \\
\text { modules) Why? }\end{array}$ \\
\hline & & $\begin{array}{l}\text { Does company name_participate in or have its } \\
\text { own take-back program? Why or why not? } \\
\text { Does this apply only to post-consumer PV waste? } \\
\text { Or also to manufacturing scrap? }\end{array}$ \\
\hline & & $\begin{array}{l}\text { (Participate) How does the participation program } \\
\text { work? What are the benefits and costs? }\end{array}$ \\
\hline & & $\begin{array}{l}\text { (Individual) What is the process for a customer to } \\
\text { participate in the take-back program? }\end{array}$ \\
\hline & \multirow[t]{2}{*}{ E-waste NGO } & $\begin{array}{l}\text { How much do we understand about where current } \\
\text { PV waste goes in California? }\end{array}$ \\
\hline & & $\begin{array}{l}\text { Can you explain how EOL PV and manufacturing } \\
\text { waste is managed in California? }\end{array}$ \\
\hline \multirow[t]{3}{*}{$\begin{array}{l}\text { Extended } \\
\text { producer } \\
\text { responsibility }\end{array}$} & \multirow[t]{3}{*}{ Manufacturer } & $\begin{array}{l}\text { Does__company name__ consider implementing } \\
\text { Extended Producer Responsibility (EPR) for PV } \\
\text { waste? }\end{array}$ \\
\hline & & $\begin{array}{l}\text { Will (or has) _ company name_ implement(ed) } \\
\text { EPR? What are the costs and benefits? }\end{array}$ \\
\hline & & $\begin{array}{l}\text { Why does _ company name_ not implement } \\
\text { EPR? }\end{array}$ \\
\hline
\end{tabular}




\begin{tabular}{|c|c|}
\hline & Who should be responsible to the PV waste? \\
\hline & $\begin{array}{l}\text { What might make_company name_consider } \\
\text { implementing EPR in the future? }\end{array}$ \\
\hline \multirow[t]{2}{*}{$\begin{array}{l}\text { PV } \\
\text { Organization }\end{array}$} & $\begin{array}{l}\text { How does the take-back and recycling program } \\
\text { work with different companies? What are the costs } \\
\text { and benefits? }\end{array}$ \\
\hline & $\begin{array}{l}\text { How can companies work to improve } \\
\text { collaboration? }\end{array}$ \\
\hline \multirow[t]{3}{*}{ Installer } & $\begin{array}{l}\text { What is your partnership with manufacturer? How } \\
\text { does_company name__ chose manufacturers to } \\
\text { work with? }\end{array}$ \\
\hline & $\begin{array}{l}\text { Do you think EPR is important to the solar industry } \\
\text { in the long-term? Is it important to develop take- } \\
\text { back and recycling programs now? }\end{array}$ \\
\hline & $\begin{array}{l}\text { How you think _company name_ can help to } \\
\text { recycle the PV waste? }\end{array}$ \\
\hline \multirow[t]{3}{*}{$\begin{array}{l}\text { E-waste } \\
\text { recycler }\end{array}$} & $\begin{array}{l}\text { Does__company name__receive PV waste? Why } \\
\text { or why not }\end{array}$ \\
\hline & $\begin{array}{l}\text { Will_company name__accept PV waste in the } \\
\text { future? }\end{array}$ \\
\hline & $\begin{array}{l}\text { What are the costs and benefits and how to improve } \\
\text { the operation? (In terms of regulation, economic } \\
\text { incentives, collaboration between industry etc.) }\end{array}$ \\
\hline
\end{tabular}




\section{Appendix B: PV Waste Flow and Interview Questions}

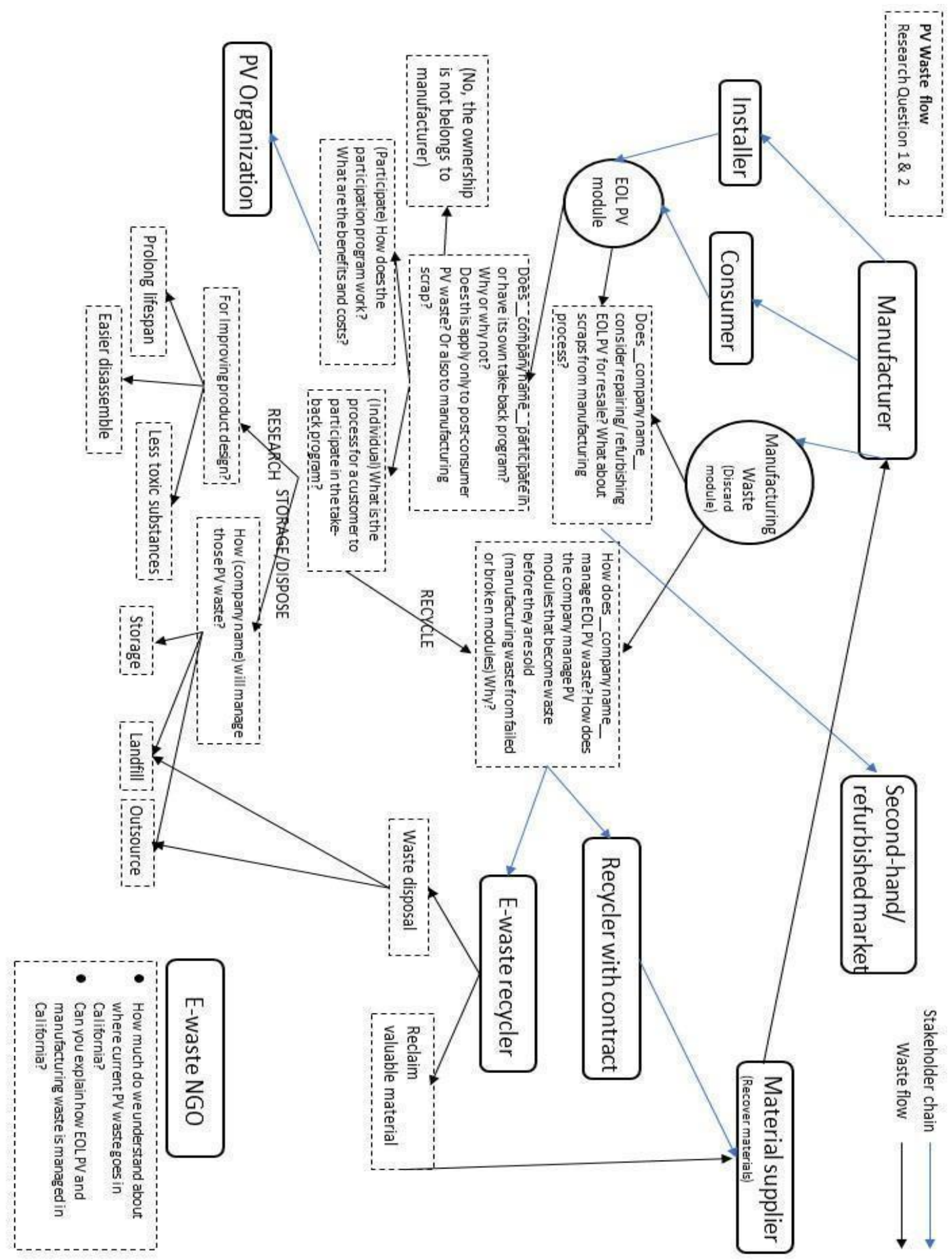




\section{Appendix C: EPR and stakeholders and interview questions}

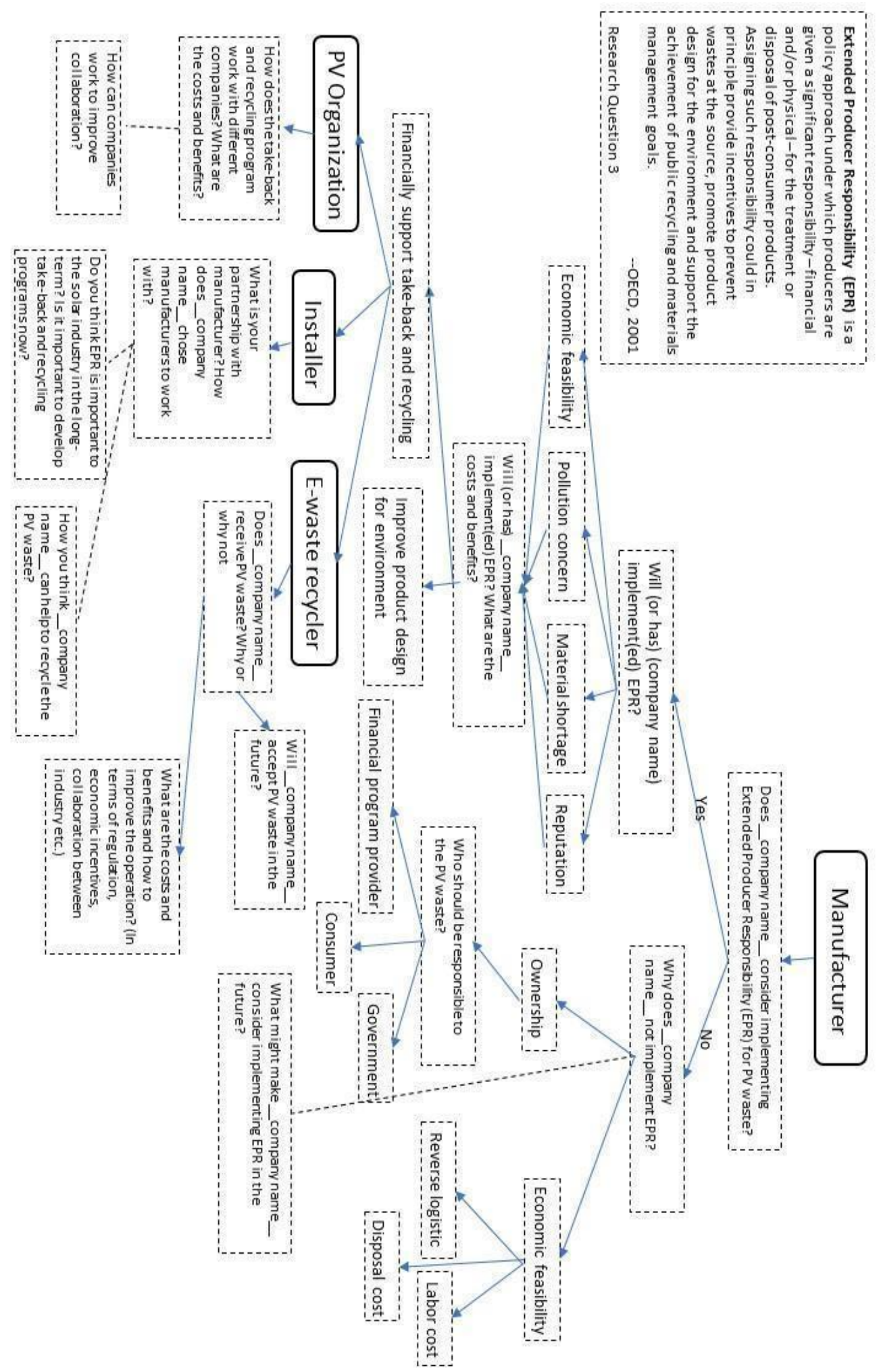




\section{Appendix D: Consent Form for Participation in Research}

\section{Title of Study}

Photovoltaic Waste Management and Implementing Extended Producer

Responsibility in the Solar Industry in California

\section{Name of Researcher}

Lee-Tan Lu, Graduate program, investigator

Department of Environmental Studies, San Jose State University

Dr. Dustin Mulvaney, faculty, primary supervisor of the study

Department of Environmental Studies, San Jose State University

\section{Purpose}

The purpose of this study is to investigate your experience and perspective of the photovoltaic (PV) waste management in California, since you are considered a stakeholder in the PV supply chain. The results of this study will be used to picture the management of the PV waste flows in California and provide overall information regarding PV waste management for future policy design.

\section{Procedures}

The interview for this study will be held in the place and time which are both convenient and available for both you and investigator. In the beginning of the interview, investigator will explain the purpose of the study and start record the interview as video form by using Apple iPad Air in the whole process. Then, investigator will start asking the questions regarding the research to you. The interview is expected to be conducted in about one hour. After the interview, investigator will organize and analyze the content. A summary conclusion of the content will send back to you for confirmation.

\section{Potential risks}

There are no known risks to participating in this study.

\section{Potential benefits}

There is no direct benefit of this research to you, but your answer could contribute to the future design of PV modules and PV waste management. It could help to reduce the waste generated from PV modules, conserve raw materials, and prevent pollutions etc. and pursue the goal of sustainable industry.

\section{Compensation}

There is no compensation to you while participating in this research.

\section{Confidentiality}

All the interview content will be stored in researcher's hard drive with password 
protection. The identifiable information you provided will be collected for investigator to identify the stakeholder's role in the PV module supply chain. For example, respondent $\mathrm{A}, \mathrm{B}$, and $\mathrm{C}$ are working in the company respectively that represent "manufacturer" in the PV module supply chain, then investigator will need their name, position in the company and company name for identification during analysis. But, the identifiable information for each respondent will not be reported in the project and presentation. The investigator will create pseudonyms for each respondent for confidentiality. All respondents' identifiable information will be deleted after three years when researcher complete of the study.

\section{Participant rights}

Your participation in this study is completely voluntary. You can refuse to participate the entire study or any part of the study without any negative effect on your relations with San Jose State University. You also have the right to skip any question you do not wish to answer. This consent form is not a contract. It is a written explanation of what will happen during the study if you decide to participate. You will not waive any rights if you choose not to participate, and there is no penalty for stopping your participation in the study.

\section{Questions or problems}

You are encouraged to ask questions at any time during this study.

- For further information about the study, please contact Lee-Tan Lu by e-mail: leetanlu@gmail.com or by phone: 408-753-5613

- Complaints about the research may be presented to Department of Environmental Studies Chair Lynne Trulio by email: lynne.trulio@sjsu.edu or by phone: $408-924-5445$

- For questions about participants' rights or if you have been harmed in any way by your participation in this study, please contact Dr. Pamela Stacks, Associate Vice President of the Office of Research, San Jose State University, at 408-9242479 


\section{Signatures}

Your signature indicates that you voluntarily agree to be a part of the study, that the details of the study have been explained to you, that you have been given time to read this document, and that your questions have been answered. You will receive a copy of this consent form for your records.

\section{Participant signature}

Participant's Name (printed) Participant's Signature Date

\section{Researcher statement}

I certify that the participant has been given adequate time to learn about the study and ask questions. It is my opinion that the participant understands his/her rights and the purpose, risks, benefits, and procedures of the research and has voluntarily agreed to participate. 


\section{Appendix E: Methodology for PV Waste Projection}

The following instruction is the methodology for projecting PV waste growth in the San Francisco Bay Area and the estimated sources of PV waste in the study. Raw data were extracted from California Distributed Generation Statistics. In this study, the "NEM_CurrentlyInterconnectedDataset_2018-10-31" was included in the analysis because there were no repeated applications in this dataset. The dataset was updated monthly, and this study used the latest data at a given time in order to run the analysis after confirming the method and the process. The raw data include: Application Id, status, geographical information for service region, technology type, system size in DC and AC (MW), et cetera.

After examining the raw data, this study kept the Application ID, geographical information, system size, and application approved date for spatial analysis (as secondary raw data). In order to improve the accuracy of the geographical distribution, this study used the smallest geographic scale (zip code) from the dataset; total system DC produced per zip code was also used for estimating the PV system in metric tonnes (IRENA and IEA-PVPS, 2016); application approved date was used for estimating the start date of the PV system in order to project the waste growth in that region. The following are the steps for converting the total system DC into the PV system metric tonnes:

1. Identify the locations that install PV modules by year (application approved date), extracted data by using "advanced filter" in the new Excel worksheet to take the data from "secondary raw data".

2. Use a pivot table to summarize the system size DC value by zip code.

3. Convert the installed DC system size (MW) into estimated system mass volume, as shown in Figure E1:

\begin{tabular}{|c|c|c|c|c|}
\hline \multirow{2}{*}{$\begin{array}{l}P 018 \\
\end{array}$} & \multicolumn{2}{|l|}{$Q$} & $\mathrm{R}$ & $s$ \\
\hline & Row Labels & $=$ & \multicolumn{2}{|c|}{ Sum of System $\mathbf{S}$ estimated' } \\
\hline & 94002 & & 210.239 & 16819.12 \\
\hline & 94005 & & 17.869 & 1429.52 \\
\hline & 94010 & & 994.893 & 79591.44 \\
\hline & 94014 & & 157.381 & 12590.48 \\
\hline & 94015 & & 213.419 & 17073.52 \\
\hline & 94018 & & 92.006 & 7360.48 \\
\hline & 94019 & & 117.379 & 9390.32 \\
\hline & 94020 & & 30.23 & 2418.4 \\
\hline
\end{tabular}

Figure E1. Converted the System DC into estimated mass volume. This part of the worksheet is for the PV system that were assumed to be built in 2018 from the application approved date. In this case, the estimated mass was converted by multiplying 80 (tons) from the sum of the PV system in that zip code area, the function as shown below:

=GETPIVOTDATA("System Size DC",\$Q\$1,"Service Zip",\$Q2)*80.

Since the data were collected till October 2018, this study categorized the estimated mass into three parts: PV system installed from 1996 - 2000 were assumed 
having $120 \mathrm{t} / \mathrm{MW}$; installed between 2001 - 2010 were assumed having 100t/MW; installed after 2011 were assumed having $80 \mathrm{t} / \mathrm{MW}$. The referenced weight-to-power ratio can be found from below figure $\mathrm{E} 2$ :

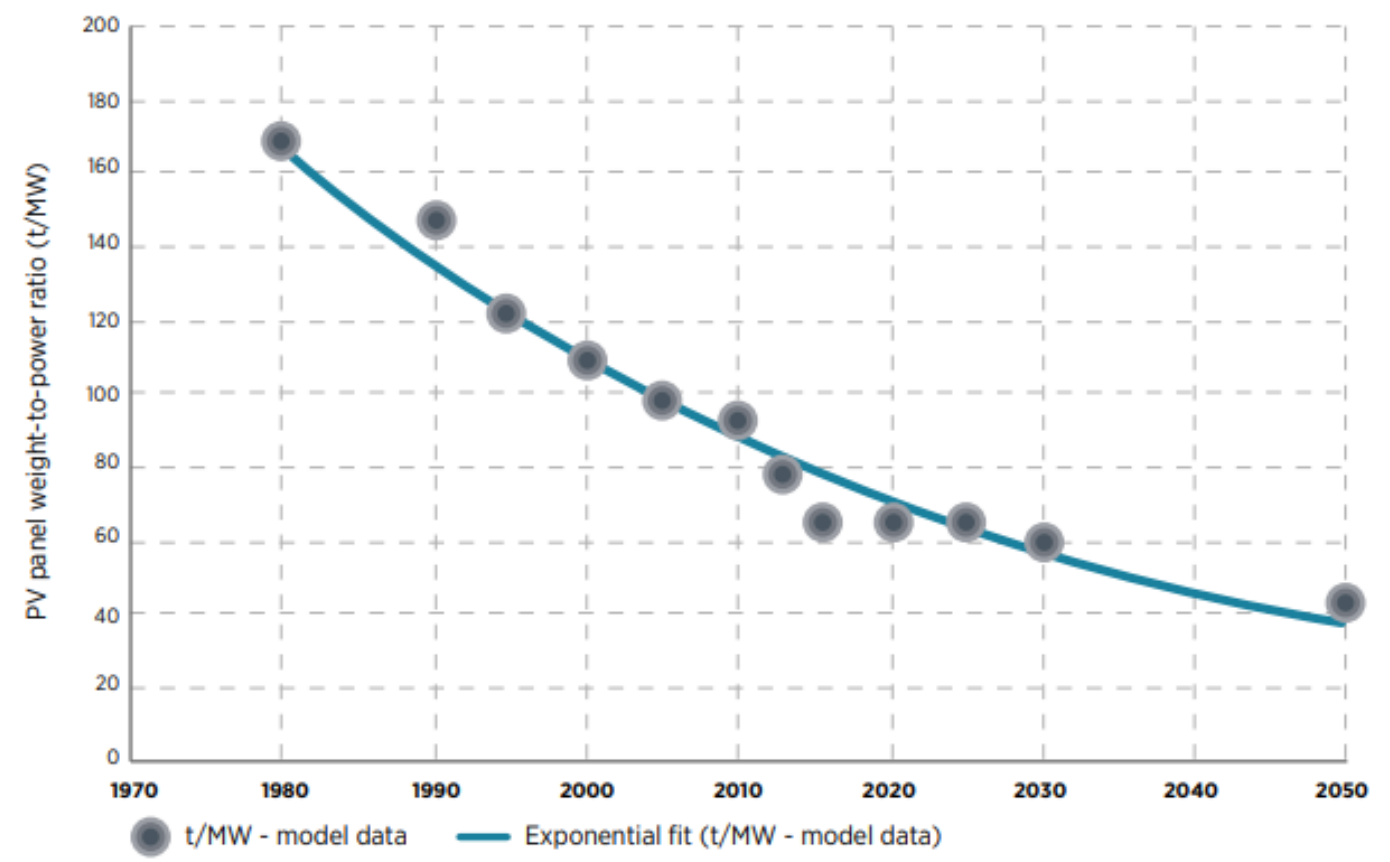

Figure E2. The PV panel weight-to-power ratio table. Source: End-of-Life Management: Solar Photovoltaic Panels by IRENA and IEA-PVPS, 2016.

4. Follow the Weibull function (Equation 1.0) from the IRENA-IEAPVPS (2016) report, using early-/regular-loss alpha value (for early-loss: 2.4928, regular-loss: 5.3759) to project the waste growth until 2050 in the San Francisco Bay Area. The average PV lifespan (T) used in this study was 30 years.

$$
\begin{aligned}
& \text { where } \quad F(t)=1-e^{-\left(\frac{t}{T}\right)^{\alpha}} \\
& t=\text { time in years } \\
& T=\text { average lifetime } \\
& \alpha=\text { shape factor, which controls the } \\
& \text { typical S shape of the Weibull curve }
\end{aligned}
$$




\begin{tabular}{|c|c|c|c|c|c|c|c|c|c|}
\hline$\checkmark$ & & $=\$ S 8^{*}(1-$ & $\operatorname{EXP}(-(((V \$ 1-\$ P \$ 1) / 30$ & $\left.0)^{\wedge} 5.3759()\right) 1$ & & & & & \\
\hline & $\mathrm{P}$ & Q & $\mathrm{R}$ & s & T & u & $\mathrm{V}$ & w & $\mathrm{x}$ \\
\hline & 2009 & Row Labels & Sum of System Size DC & estimatedW & & 2010 & 2011 & 2012 & 20: \\
\hline & & 93519 & 11.796 & 1179.600 & 93519 & $1.35169 \mathrm{E}-05$ & 0.000561 & 0.004964 & $0.0233 c$ \\
\hline & & 94002 & 58.467 & 5846.700 & 94002 & $6.69969 \mathrm{E}-05$ & 0.002782 & 0.024604 & $0.1155:$ \\
\hline & & 94010 & 318.880 & 31888.000 & 94010 & 0.000365402 & 0.015173 & 0.134192 & 0.6300 : \\
\hline & & 94014 & 16.678 & 1667.800 & 94014 & $1.91112 \mathrm{E}-05$ & 0.000794 & 0.007018 & 0.0329 : \\
\hline & & 94018 & 23.670 & 2367.000 & 94018 & $2.71233 \mathrm{E}-05$ & 0.001126 & 0.009961 & $0.0467 t$ \\
\hline & & 94019 & 28.342 & 2834.200 & 94019 & $3.24769 \mathrm{E}-05$ & 0.001349 & 0.011927 & 0.05 \\
\hline & & 94020 & 7.548 & 754.800 & 94020 & $8.6492 \mathrm{E}-06$ & 0.000359 & 0.003176 & 0.0149 : \\
\hline & & 94022 & 470.590 & 47059.000 & 94022 & 0.000539246 & 0.022392 & 0.198035 & $0.9298:$ \\
\hline & & 94024 & 409.426 & 40942.600 & 94024 & 0.000469158 & 0.019482 & 0.172296 & $0.8089 t$ \\
\hline & & 94025 & 124.100 & 12410.000 & 94025 & 0.000142205 & 0.005905 & 0.052224 & $0.2452 c$ \\
\hline & & 94027 & 191.552 & 19155.200 & 94027 & 0.000219498 & 0.009115 & 0.080609 & $0.3784 i$ \\
\hline
\end{tabular}

Figure E4. Translated Weibull function into MS Excel. This part of the worksheet shows the projected PV waste volume by using Weibull function along with the years that PV system has been installed. The Weibull function (Equation 1.0) is used by IRENA-IEAPVPS (2016), then converted to Excel in this analysis like this: $=$ estimated mass*(1-(EXP(-(((“current” year-installed year)/average lifespan $) \wedge$ alpha value)))) "current" year was changed along the time the PV system installed to project the waste growth.

5. Consolidate all the data from each year by zip code into one worksheet, differentiated by the early-/regular- loss scenario (see Figure E5). Data was organized according to the labels (in this case, zip code and year).

\begin{tabular}{|c|c|c|c|c|c|c|c|c|c|c|c|c|c|c|c|c|c|c|}
\hline $\mathrm{AO}$ & & $\vdots$ & $\checkmark$ & $f_{x}$ & 36.566783 & 39814611 & & & & & & & & & & & & \\
\hline 4 & A & B & c & D & $\mathrm{E}$ & $\mathrm{F}$ & G & $\mathrm{H}$ & 1 & J & K & L & M & $\mathrm{N}$ & 0 & P & Q & \\
\hline 1 & & 1997 & 1998 & 1999 & 2000 & 2001 & 2002 & 2003 & 2004 & 2005 & 2006 & 2007 & 2008 & 2009 & 2010 & 2011 & 2012 & \\
\hline 2 & 94514 & & & & & & $2.6 \mathrm{E}-06$ & 0.00011 & 0.00097 & 0.00489 & 0.01868 & 0.05978 & 0.16764 & 0.42213 & 0.97021 & 2.06295 & 4.10838 & $7 . i$ \\
\hline 3 & 94515 & $3.2 \mathrm{E}-06$ & 0.00013 & 0.00119 & 0.00558 & 0.01852 & 0.04936 & 0.11319 & 0.23314 & 0.4439 & 0.80111 & 1.41008 & 2.48233 & 4.44022 & 8.11263 & 15.0546 & 27.9867 & 51 \\
\hline 4 & 94030 & & & & & & & & $1.1 \mathrm{E}-05$ & 0.00047 & 0.00481 & 0.02608 & 0.09798 & 0.2914 & 0.73813 & 1.66359 & 3.43434 & 6.6 \\
\hline 5 & 94035 & & & & & & & & & & & & & & & 4.5E-06 & 0.00019 & 0.6 \\
\hline 6 & 94037 & & & & & & & 7E-06 & 0.0003 & 0.00285 & 0.01485 & 0.05483 & 0.16113 & 0.40255 & 0.89256 & 1.81014 & 3.43194 & 6.1 \\
\hline 7 & 94038 & & & $5.5 \mathrm{E}-06$ & 0.00023 & 0.00204 & 0.00956 & 0.03172 & 0.08489 & 0.19719 & 0.41516 & 0.8124 & 1.49998 & 2.63942 & 4.45843 & 7.26947 & 11.4913 & 17 \\
\hline 8 & 94101 & & & & & & & & & & & & & & & & & 3. \\
\hline 9 & 94102 & & & & & & & & & $1.3 \mathrm{E}-06$ & $8.6 \mathrm{E}-05$ & 0.00177 & 0.01369 & 0.06234 & 0.20807 & 0.5662 & 1.33459 & $2 . \varepsilon$ \\
\hline 10 & 94088 & & & & & & & & & & & & & & & & $2.3 \mathrm{E}-05$ & $0 . c$ \\
\hline 11 & 94089 & & & & & & & & & & & & & 0.00023 & 0.0096 & 0.08556 & 0.40584 & 1.8 \\
\hline 12 & 94103 & & & & & & & $6.1 \mathrm{E}-06$ & 0.00025 & 0.00223 & 0.01071 & 0.03824 & 0.11717 & 0.32457 & 0.82355 & 1.92791 & 4.18847 & 8.8 \\
\hline 13 & 94104 & & & & & & & & & & & & & & & & & 1. \\
\hline 14 & 94105 & & & & & & & & & & & & & & & & & \\
\hline 15 & 94107 & & $5.2 \mathrm{E}-06$ & 0.00022 & 0.00214 & 0.01093 & 0.03893 & 0.10996 & 0.26565 & 0.57461 & 1.14574 & 2.1465 & 3.82859 & 6.56635 & 10.9198 & 17.7326 & 28.2695 & 44 \\
\hline 16 & 94019 & & & & $5.2 \mathrm{E}-06$ & 0.00022 & 0.00192 & 0.00904 & 0.03105 & 0.09007 & 0.23281 & 0.54826 & 1.19613 & 2.45171 & 4.77201 & 8.8883 & 15.9236 & 27 \\
\hline 17 & 94005 & & & & & & $3.7 \mathrm{E}-06$ & 0.00015 & 0.00139 & 0.00722 & 0.02909 & 0.09751 & 0.27924 & 0.69947 & 1.5695 & 3.21916 & 6.1327 & 10 \\
\hline
\end{tabular}

Figure E5. Added up the result by year by Consolidation. This part of the worksheet shows the consolidation process that added up the different worksheets (top picture) into one worksheet (bottom picture).

6. Organize the consolidated data into proper format. This includes filling the blank cell with zero, editing the zip code number for later ArcGIS to read, et cetera.

7. Use "conditional formatting" to set the conditions of the cell to highlight those locations that might have a certain amount of the waste volume by the year of 2010 to 
2050 with 10 years gap (see Figure E6). In the current analysis, there were four categories: $15>=x>30 ; 30>=x>60 ; 60>=x>120 ; 120>=x$

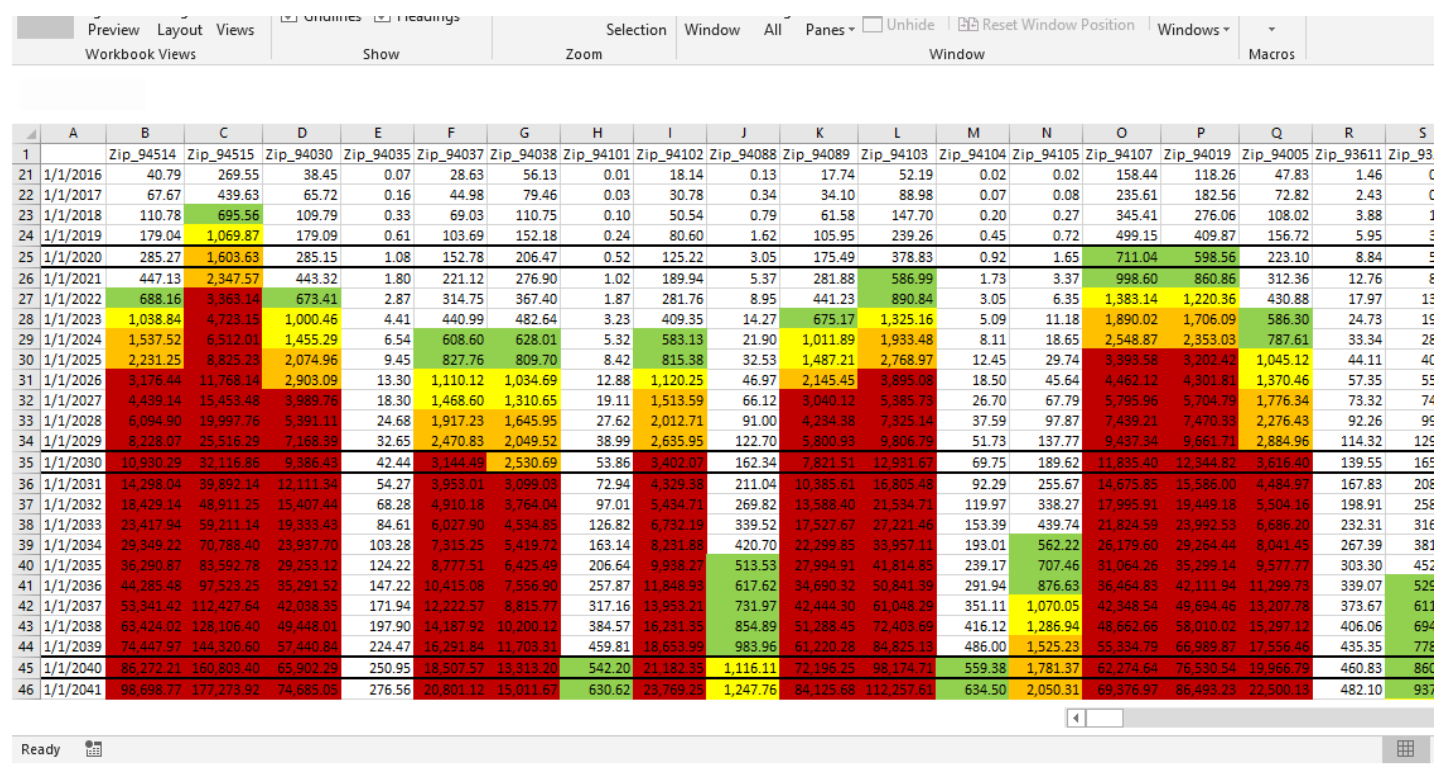

Figure E6. Visualize the value by using conditional formatting. It can color the data cells that matched each of the criterion.

8. Use "advanced filter" to extract the locations that meet the criteria, then compare with the data that were highlighted from the last step to validate if the filter is correct, see Figure E7

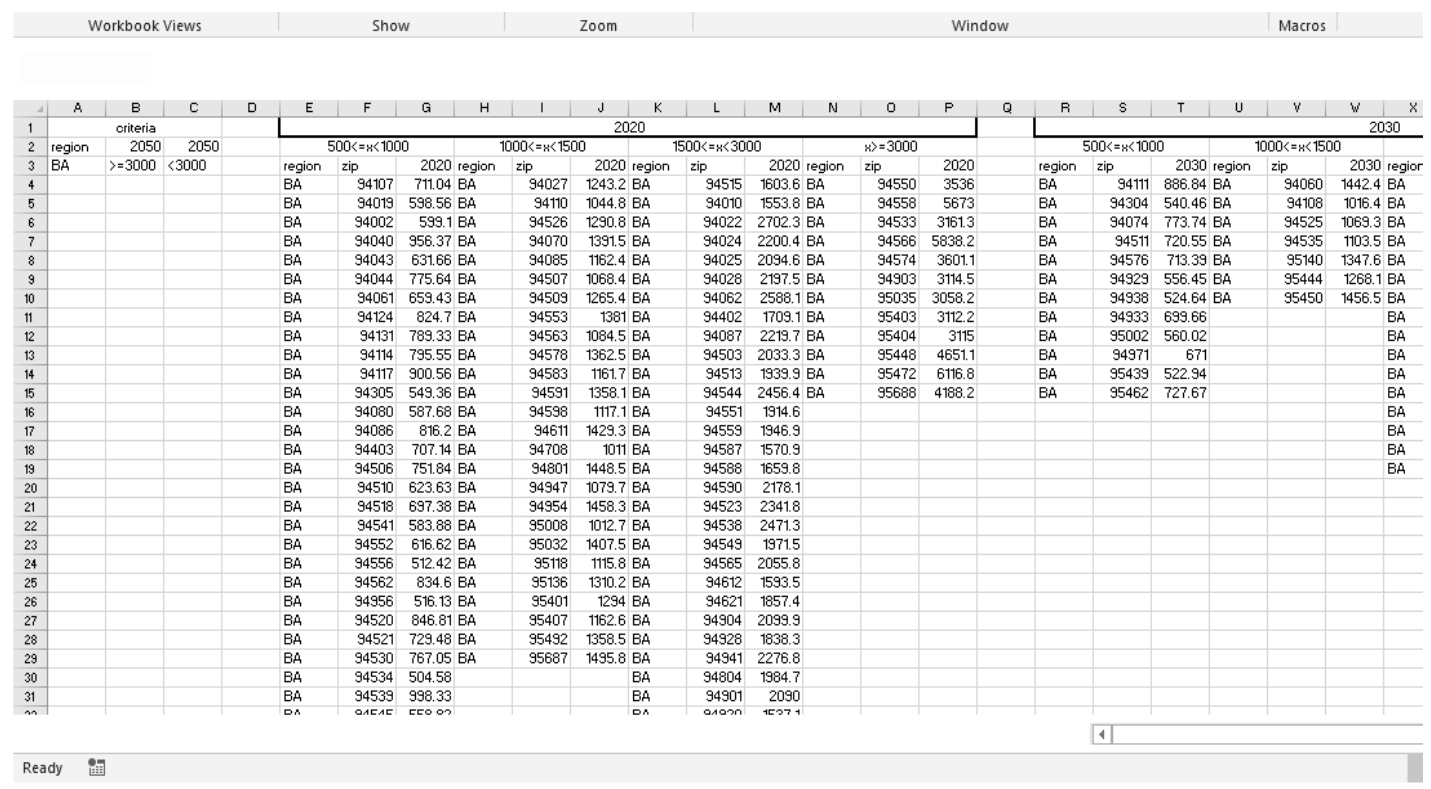

Figure E7. Advanced filter extracted the data that met the criteria. 


\section{Appendix F: Methodology for Map Creation and GHG Calculation}

The amount of PV waste per zip code area was mapped by table-joining an Excel table containing waste statistics to a zip code polygon shapefile obtained from the United States Postal Service ${ }^{2}$. Then, the resulting values were represented using blue graduated symbols, as seen in Figure F1.
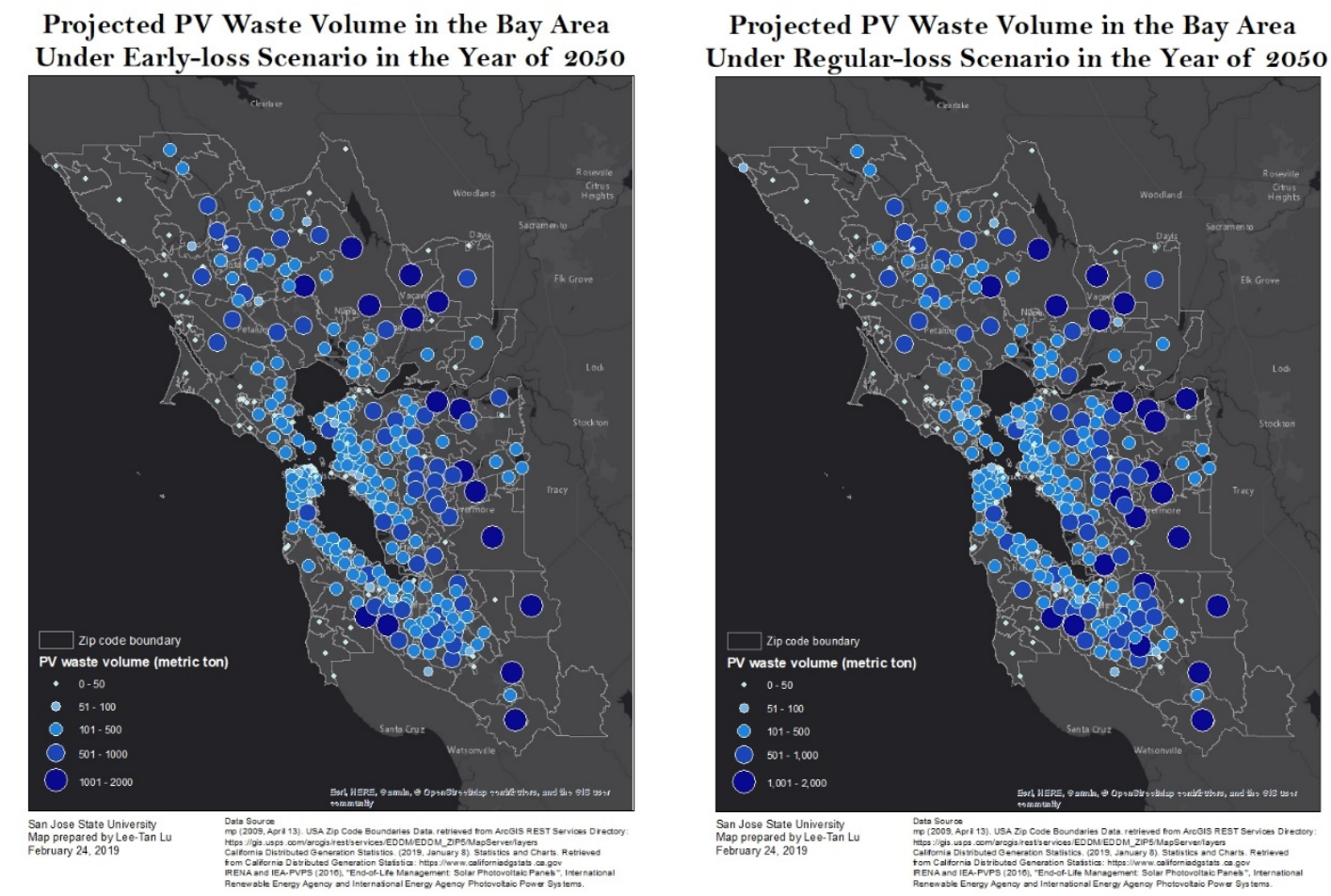

Figure F1. Projected PV waste volume under both early-/regular- loss scenarios by the year 2050.

The next step was to identify which zip code areas would have significantly higher PV waste than others. Thus, "Analyze Patterns - Find Hot Spots" in ArcGIS Online was applied. The results are shown in Figure F2.

${ }^{2}$ mp (2009, April 13). USA Zip Code Boundaries Data. retrieved from ArcGIS REST Services Directory: https://gis.usps.com/arcgis/rest/services/EDDM/EDDM_ZIP5/MapServer/layers 
Hot Spots Analysis of PV Waste Volume in the Bay Area Under Early-loss Scenario in 2050

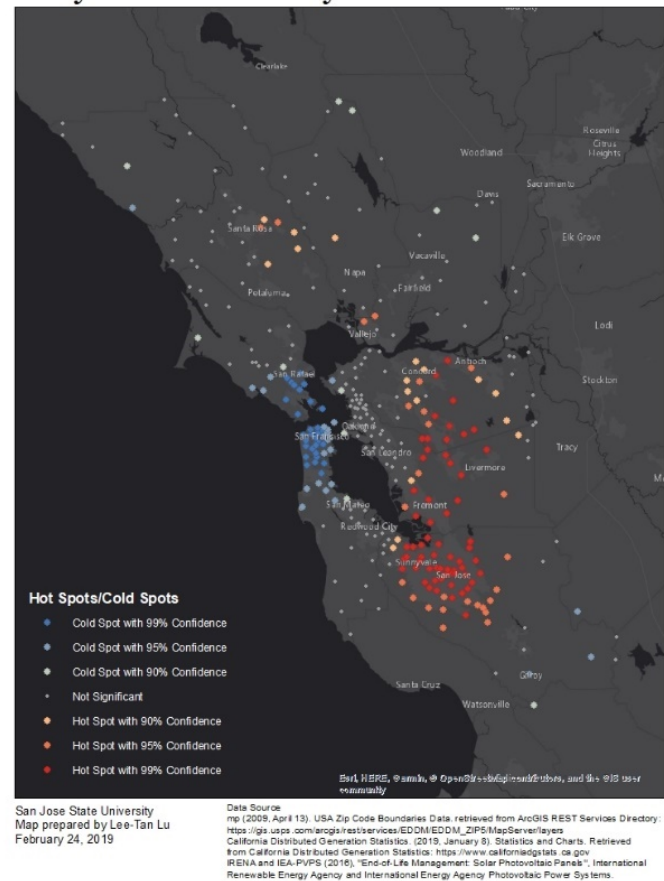

Hot Spots Analysis of PV Waste Volume in the Bay Area Under Regular-loss Scenario in 2050

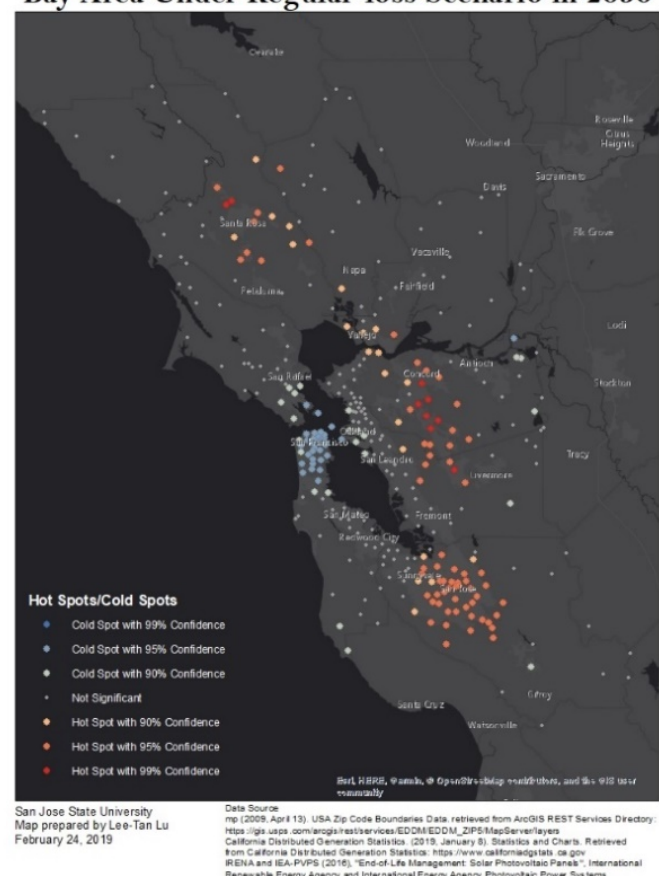

Figure F2. Hot/cold spots of the PV waste in the San Francisco Bay Area in the year of 2050 under the early-/regular- loss scenario.

After finding that the North, East, and the South Bay have higher PV waste volume, ArcGIS Online's "Summarize Data - Summarize Center and Dispersion" function helped to pinpoint the location that has the shortest distance to all the selected features. In this study, three PV waste collection center scenarios and the assumed current PV waste destinations were presented. Each of their average distances between the waste sources to the collection sites were calculated by using "Use Proximity - Find Nearest" function in ArcGIS Online. The measurement method was "Trucking Distance," which gives preference to travel along major roads and freeways that trucking companies prefer to use. Also, a range limit of 100 miles was applied. The simulated network system can be seen in Figure F3. 

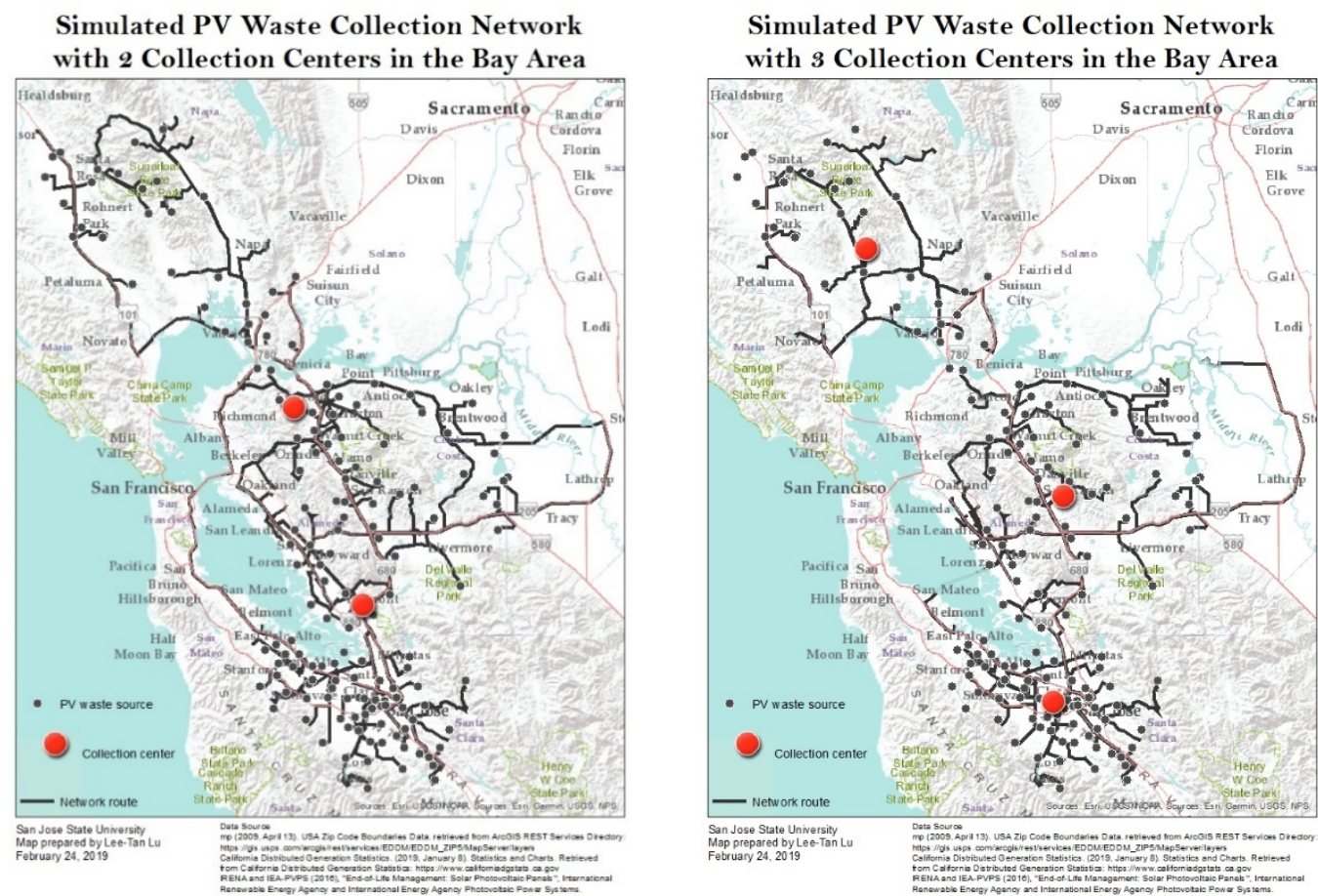

Figure F3. The maps showed the network system result with different numbers of collection center scenario.

Travel distances from the PV waste sources to the collection center and the assumed current destinations were calculated after using the "Use Proximity - Find Nearest". Then, by using the emission factors from the Environmental Protection Agency ${ }^{3}$, potential GHG emission during transportation were estimated. The calculation is:

Weight of most panels: $40-45$ pounds $->42.5$ pounds $\fallingdotseq 19.278 \mathrm{~kg}$

A truck load with proper stacked panels can move about 660 panels at once:

660 panels $* 19.278 \mathrm{~kg} /$ panel $=12,723.48 \mathrm{~kg}=12.723$ metric tons

\begin{tabular}{|l|l|l|}
\hline \multicolumn{3}{|l|}{ GHG for heavy-duty truck (unit: ton-mile) } \\
\hline Compounds & Factor & GWP (kgCO2eq) \\
\hline $\mathrm{CO} 2$ & $0.202 \mathrm{~kg} /$ unit & 1 \\
\hline $\mathrm{CH} 4$ & $0.0020 \mathrm{~g} /$ unit & 25 \\
\hline $\mathrm{N} 2 \mathrm{O}$ & $0.0015 \mathrm{~g} /$ unit & 298 \\
\hline
\end{tabular}

-> GWP for 1 functional unit of heavy-duty truck: $0.202497 \mathrm{kgCO} 2 \mathrm{eq} /$ ton-mile

-> A truck load per mile will create:

$0.202497 \mathrm{kgCO} 2 \mathrm{eq} /$ ton-mile $* 12.723$ tons $=2.576 \mathrm{kgCO} 2 \mathrm{eq} / \mathrm{mile}$

To include an economic perspective in the calculations, stakeholders' opinions and experience were considered when using ArcGIS Online's "Use Proximity - Create Drive-

${ }^{3}$ Environmental Protection Agency (2018, March 9). Emission Factors for Greenhouse Gas Inventories. Retrieved from EPA: https:/www.epa.gov/sites/production/files/2018-03/documents/emissionfactors_mar_2018_0.pdf 
Time Areas". In this calculation, an experimental estimation was used to calculate the sources of the PV waste and covered areas. The measurements were based on "Trucking Distance: 3, 5, 7 miles" that can be covered by e-waste recyclers with enough PV waste to make the operation reach net-zero. Please see Figure F4 as a reference. For future studies, more information and inputs are necessary to achieve a more accurate strategy for planning new collection sites.
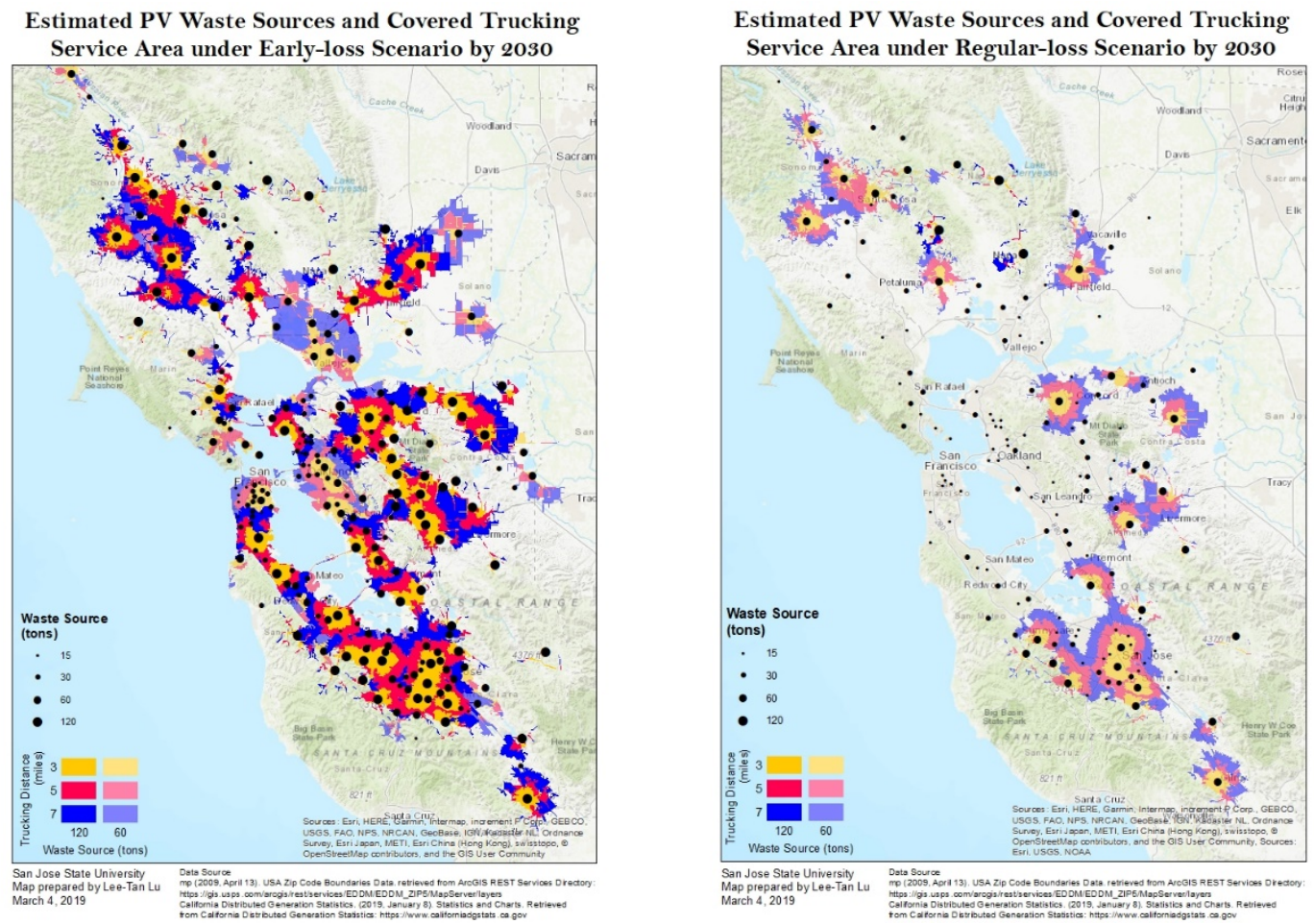

Figure F4. Both experimental maps showed the areas that could be recognized as the regions to build the collection/recycling sites with potential net-zero operation cost. 